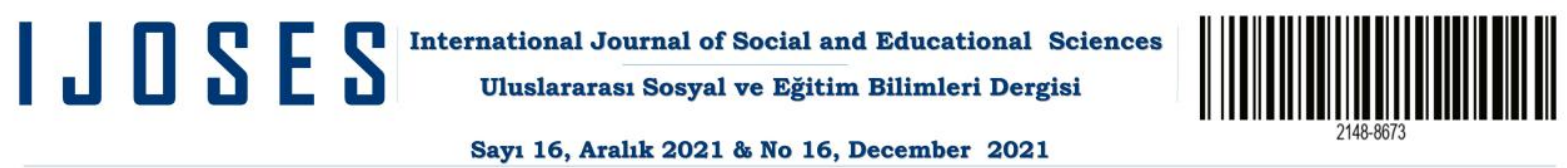

\section{Gazâlî’nin Kimliği Üzerine Klasik ve Modern Tartışmalar}

The Classical and Modern Debates on Ghazali's Identity

\section{Ramazan Gündüz}

Dr.

Diyanet İşleri Başkanlığ

rmzngndz33@gmail.com

ORCID ID: 0000-0002-7447-2487

\author{
$*$

\section{Makale Bilgisi / Article Information} \\ Makale Türü / Article Type : Araştırma Makalesi \\ Geliş Tarihi / Received : 22 Eylül 2021 \\ Kabul Tarihi / Accepted : 18 Kasim 2021 \\ Yayın Tarihi / Published : 15 Aralık 2021 \\ DOI Number : 10.20860/ijoses.999408
}

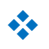

\section{Kaynak Gösterme / Citation}

Gündüz, R. “Gazâlî’nin Kimliği Üzerine Klasik ve Modern Tartışmalar ". Uluslararası Sosyal ve Eğitim Bilimleri Dergisi, 16 (2021): 123-149. 


\section{Gazâlî’nin Kimliği Üzerine Klasik ve Modern Tartışmalar}

\section{The Classical and Modern Debates on Ghazali's Identity}

\section{Ramazan Gündüz}

$\ddot{O} z$

Bu çalışmada İslam düşüncesinin klasik çağının en etkili âlimlerinden biri olan, sonraki çağlarda da fikirleri üzerinde çok fazla tartışmanın yapıldığı Huccetü'l-İslam Ebû Hâmid elGazâlî’nin kimliği üzerine ortaya konulan klasik ve modern tartışmalar konu edilmiştir. Gazali'nin fikirleri üzerinde bitmek tükenmek bilmeyen tartışmalar onun kimliğini tespit etmede de devam etmiştir. Klasik ve modern Gazâlî biyografileri onun doğum tarihinden doğum yerine, isminin etimolojisinden kimliğine, kullandığı künyeden ailesi hakkındaki bilgilere varıncaya kadar birçok husus üzerine tartışma yapmıştır. Klasik kaynakların aktardığı bilgiler, birbiri ile çelişkili olmakla beraber her bir aktarımın diğerinin bilgi değerini yok sayacak düzeyde kuvvetli hüccetlerinin bulunmaması Gazâlînin kimliğini açıklığa kavuşturmayı zorlaştırmaktadır. Modern kaynaklarda ise klasik kaynakların ortaya koyduğu Gazâlî biyografisini değiştirecek yine klasik bilgilerle güçlendirilmiş iddialar bulunmaktadır. Diğer yandan bazı modern kaynakların klasik kaynaklarda bulunmayan, yeni bir Gazâlî kimliği inşa etmeye yönelik bilgiler vermeleri, meseleyi daha da karmaşık hale getirmektedir. Bu makalede, Gazali'nin kimliği üzerine bilgiler veren, etkili klasik ve modern kaynaklar taranmış ve mesele kısmen açıklığa kavuşturulmaya çalışımıştır.

Anahtar Kelimeler: Gazâlî, Gazâlî’nin Kimliği, Doğum Tarihi, Doğum Yeri, Gazâlînnin İsmi, Gazâlî́nin Ailesi.

\section{Abstract}

This papere covered the classical and modern debates, which were put forward to called the identity of Huccetü'IIslam Abu Hâmid al-Ghazali, who was the one of the most influential scholar of the classical age of Islamic thought and about whom the most debate was made in the following ages. The endless debates over his ideas have continued in determining the identity of Ghazali. Classical and modern sources presenting a biography of al-Ghazali have tried to clarify many issues ranging from his date of birth, place of birth, the etymology of his name, his national identity, the tag he used, to the information about his family. However, although the information conveyed by classical sources are contradictory with each other, the absence of a stronger proof that will ignore the information value of the other makes it difficult to clarify the identity of Ghazali. In modern sources, there are some means reinforced with classical information that will change the biography of Ghazali revealed by classical sources. On the other hand, although it is remarkable that some modern sources provide information that was not available in classical sources in order to develop a new Ghazali identity, they are doubtful as they do not rely on a solid foundation. In this article, influential classical and modern sources that provide information on the identity of Ghazali have been researched and the issue has been tried to be partially clarified.

Keywords: Ghazali, the identity of Ghazali, the date of birth and the birthplace of Ghazali, the name of Ghazali, the family of Ghazali. 


\section{Extended Summary}

\section{The Classical and Modern Debates on Ghazali's Identity}

Imam Ghazali, one of the most prolific scholars of the classical age of Islamic thought, is a person who left his mark both in the century he lived and in the following periods. In the most turbulent period of the Islamic world culturally and politically, the ideas expressed by Ghazali, who was the most influential advocate of the Sunni understanding of Islam and who wrote works in almost all fields of Islamic sciences, have always been discussed. While some of the Muslim thinkers, who were polarized over his ideas, praised him so much that they almost compared him to the prophet, his opponents sometimes criticized him with extremely contemptuous expressions and they even accused him of takfir.

These discussions on Ghazali's ideas were also experienced in the determination of his identity. There are many independent works, articles and researches that try to construct the biography of Ghazali in classical and modern sources. In these sources, various claims have been brought up about the identity of Ghazali, from the date of his birth to his identity, from the ratio of his name to his place of birth, from his affiliation in the creed to his nationality. The classical sources, which are not much disputed about the date of Ghazali's birth, are almost allied in the year 450/1058. Although the majority of modern sources repeat the date of birth given by classical sources, Frank Griffel's work on this issue contains historical arguments that reveal that the known date of birth of Ghazali should be changed. Griffel, by building his arguments on the dates given by Ghazali himself, changed the date of Ghazali's birth to date 448/1056. Griffel's determination must be convincing, as some of the recently written biographies of Ghazali have also started to use the date Griffel has determined. The debates over his birthplace have also revealed a debate that affects the choice of al-Ghazali (single-z) or al-Ghazali (double-z) etymology, in parallel with the issue of how to pronounce his name. Accordingly, the pronunciation of al-Ghazali ( single $\mathrm{z}$ ) is because he was born in a village called Ghazali. Al-Ghazali (double z) etymology is related to the profession of Ghazali's father.

Classical biography sources do not give us any information about whether Ghazali's nationality is Arab or Persian. Modern sources, on the other hand, seem to have discussed Ghazali's race considerably. Most of the sources insist that Ghazali is of Persian/Iranian origin. However, M. Rashid Riza, in the series of articles he wrote on al-Ghazali in the journal al-Menar, presented convincing evidence that Ghazali might be an Arab contrary to what is claimed.

Ghazali is one of the most nicknamed personality among Muslim thinkers. Ghazali was given some nicknames by the Seljuk rulers and Abbasid caliphs while he was still alive. He was given the nickname Huccetü'l-Islam by the Abbasid caliph because he strengthened the Sunni thought with intellectual arguments against Bâtinism. And so, this nickname surpassed even his name by overshadowing other nicknames. Although it is a fact that everyone accepts that Ghazali is a Sunni Islamic scholar who is at least formally devoted to Ash'ari kalam and Shafi'i fiqh, some Shiite thinkers have made an effort to connect Ghazali with Shiism. There are thinkers from both Isnaashare Shiites and Ismaili Shiites who try to portray Ghazali as a person who adopted Shiism. The arguments about Ghazali's Shi'ism put forward by these thinkers contain some inconsistencies. Especially the modern Ismaili thinker Arif Tâmir's effort to portray al-Ghazali as an Ismaili sympathizer is an anachronistic approach that is the product of esoteric mysticism. 
Although there is not much detailed information about Ghazali's family in classical sources, there are some records about other Ghazali from Ghazali's family, Ghazali's brother Ahmed al-Ghazali and his other siblings. Classical sources have no information as to whether he has a sister or not. However, some twentieth-century intellectuals have claimed that his sister was too. Although it is certain that Ghazali's daughters lived after him, it was discussed whether he had a son or not. Although the general opinion is that he did not have a son who lived after him, some classical arguments put forward the opinion that Ghazali's lineage may have been continued by his son. Important Islamic historians such as Ibn Hajar, Ibnu'l-Imad and Sahavi have mentioned some personalities descended from Ghazali in their works and have given the lineage of these personalities back to Ghazali. Kadi Ahmed of Niğde, a classical Seljuk historical author, also tried to prove his wife's claims that his lineage was based on a son of Ghazali with the genealogy he mentioned. Abdülgafir al-Farisi, who is the oldest source on the biography of Ghazali, states that Ghazali only had daughters. This contradictory information brings to mind the possibility that the lineage lines of the people who are shown as the sons of Ghazali are mixed with other Ghazali.

The point that classical and modern sources agree about Ghazali is the date of his death. Recent archaeological excavations show that Ghazali's tomb is in a different location than the known place. Until recently, It was known that Ghazli's tomb was at the place of Harun er-Rashid's maussoleum, also called as Haruniyye, or at its backyard, but as a result of the excavations carried out in 2007, it was determined that Ghazali's tomb was in an empty area outside the old Tus walls.

\section{Gazâlî’nin Doğum Tarihi}

Klasik ve modern biyografi eserlerinin çoğunda Gazâlî'nin doğum tarihi h. 450/1058 olarak verilmektedirler. Klasik kaynaklarda sadece y1l zikredilmekte olup gün ve ay belirtilmemekle beraber modern kaynaklardan Muhammed Rızâ'nın (ö. 1950) kaleme aldığg Ebû Hâmid el-Gazâlî isimli eserde Gazâlî’nin doğduğu ay hicrî takvime göre Zilkâde ayıdır. (Rızâ, 1924, s. 2). Modern dönemde Gazâlî üzerine en yetkin otoritelerden biri olan Frank Griffel ise Gazâlî’nin doğum tarihinin miladi y1la göre Mart 1058 veya Şubat 1059 olduğunu belirtir. (Griffel, 2012, s. 50).

Gazâlî’nin biyografisi hakkında bilgi veren en erken kaynak Gazâlî’nin çağdaşı ayrıca Gazâlî’nin Horasan'da sohbetine katılmış bulunan (Zerrinkub, 2007), s. 17) Abdülğâfir el-Fârisî'nin (ö. 529/113435) telif ettiği Kitabü's-Siyâk li-Târihi Nîsâbûr adlı eserdir. (Kandemir, 1998, s. 1/203-105). Bu eserin Gazâlî’nin biyografini içeren kısmı özgün haliyle günümüze ulaşmamış görünüyor. Mustafa Çağrıcı bu eserin kayıp olduğu bilgisini vermekte ise de bkz., (Çağrıcı, 1996, s 13: 530) Kandemir, el-Fârisî'nin eserlerini zikrederken bu eserin yazma nüshasının Ankara Dil ve Tarih-Coğrafya Fakültesi Kütüphanesi'nde (İsmail Saib Sencer, nr. 1544), Zeylü Târihu Nîsâbûr adıyla kayıtlı bulunduğunu söylemektedir. Bkz., (Kandemir, 1998, s. 1: 204). Fakat bu yazmanın ef-Fârîsî’nin eserinin tümünü kapsamadığı, Gazâlî hakkındaki kayıtları içermeyen ikinci kısmından ibaret olduğu Richard N. Frye tarafından yapılan tıpkı basım neşrinden anlaşılmıştır. (Frye, 1965, s. 10). Daha sonraki kaynaklar genelde el-Fârisî'nin bu eserine dayanarak bize bilgi aktarmaktadırlar. el-Fârîsî’nin Gazâlî biyografisini içeren kaydının özet halini İbrâhîm ibn Muhammed es-Sarîfînî (ö. 641/1243) Târîh-i Nîşâbûr elMüntehab mine's-Siyâk adlı eserinde nakletmektedir. (es-Sarîfînî, 1362/1983), s. 83-85). el-Fârîsî'nin Gazâlî metninin tam hali ise Tâceddîn es-Sübkî'nin (ö. 771/1370) Tabakâtü 'ş-Şâfi 'iyyeti 'l-Kübra'sinda aktarılmaktadır. (Sübkî, 1403/1982, s. 206-2016). Gazâlî’ye en yakın biyografi yazarlarından 
Abdülkerîm b. Muhammed es-Sem'ânî (ö. 562/1166) nisbeleri esas alarak yazdı̆̆ı el-Ensâb adlı biyografi eserinde "el-ğazâl” maddesini incelerken Gazâlî'ye yer vermemektedir. (es-Sem'ânî, 1962, s. 10: 31-33). İbn Asâkir (ö. 571/1175) ise el-Eş’arî (ö. 324/935-36) savunması yaptığ1 Tebyînü Kezibi'lMüfterî ile Dımaşk (Şam) ve Suriye' deki diğer bazı şehirlerle ilgili bilgilere yer verdiği Târîhu Medîneti Dımaşk adlı eserlerinde el-Fârisî’ye dayanarak Gazâlî’nin hayatından pasajlar aktarır. (İbn Asâkir, 1404/1981, s. 291-296; a. mlf., 1995, s. 55: 200-204). el-Fârisî’ye dayanarak Gazâlî hakkında bilgi aktaran bu klasik kaynaklarda Gazâlî'nin doğum tarihi hakkında bir bilgi bulunmamaktadır. Sadece Sarîfînî el-Fârîsi'nin Kitabü's-Siyâk'ından özetlediği el-Müntehab mine's-Siyâk adlı eserinde Gazâlî'nin doğum tarihi ile alakalı "450 tarihinde doğdu; denildi ki o Taberan'da 451 tarihinde doğmuştur." şeklinde bir ifade aktarır. (Sarîfînî, 1362/1983, s. 84). Ancak bu ifadenin Sarîfî'nin asıl metninde olmadığı, eseri yayıma hazırlayan Muhammed Kâzım el-Mahmûdî’nin tasarrufu olduğu gerek bu ifadenin parantez içinde verilmesinden gerekse ilgili eserin el yazmasının tıpkı basım neşrini yapan Richard N. Frye'in çalışmasından anlaşılmaktadır. ( Frye, yazma, ts.,2, 20b).

Gazâlî'nin doğum tarihini ilk zikreden İbnü'l-Cevzî'dir. (ö. 597/1201) O, el-Muntazam fi Târîhi'lMülûk ve'l-Ümem adlı eserinde Gazâlî'nin doğum tarihini h. 450 olarak zikreder. (İbnü'l-Cevzî, 1992, s. 17: 124). Bu tarih daha sonraki bütün Gazâlî biyografilerinde üzerine ittifak edilmiş tarihtir. İbnü'1Cevzî'den sonraki biyografi müelliflerinin hepsi bu tarihi muhafaza etmekle beraber yine İbnü'l-Cevzi diğer bir eserinde itimada şayan görmeyerek "glle", (denilir ki) şeklinde bir ifadeyle Gazâlî'nin doğum tarihinin h. 451 olduğunu ifade eder. (İbnü'l-Cevzî, 1406/1985, 178). Anlaşılan o ki, Gazâlî’nin doğum tarihini veren ilk kişi İbnü'l-Cevzî olduğu gibi bu tarih hakkındaki ihtilafi da başlatan İbnü'l-Cevzî'dir. Aynı dönemin tarihçisi sayılan Yâkût el-Hamevî (ö. 626/1228) sadece h. 450 tarihini Gazâlî’nin doğumu olarak kaydeder. (el-Hamevî, 1995, s. 4: 49). İbnü'l-Cevzî'nin torunu Sibt İbnü'l-Cevzî (ö. 654/1256) de bu ihtilafa iltifat etmeden dedesi İbnü'l-Cevzî'ye dayanarak h. 450 tarihini aktarır. (Sibt İbnü'l-Cevzî, 2013, s. 20: 50). Yaşadıkları dönem Gazâlî' den yaklaşık bir asırdan daha fazla bir zamana tekabül eden İbnü'l-Esîr (ö. 630/1233) Gazâlî’nin doğum tarihini zikretmezken İbnü’s-Salâh (ö. 643/1245) h. 450 tarihini esas alır. (İbnü's-Salâh, 1992, 1: 249). İbn Hallikân (ö. 681/1282) h. 450 tarihini vermekle beraber Taberân'da Gazâlî'nin doğum tarihinin h. 451 olarak telaffuz edildiğini aktarır. (İbn Hallikân, 1971, s. 4: 218). Daha sonraki kaynaklardan es-Sadefî (ö.764/1363) de İbn Hallikân'ın verdiği bilgiyi aynen tekrar eder. (es-Sadefî, 2000, s. 1: 213). Şafî̂ fakihi İsnevî (ö.772/1370) ise Tabakâtü'şŞâfi'iyye'sinde sadece h. 450 yılını Gazâlî'nin doğum yılı olarak belirtir. (el-İsnevî, 2002, s. 2: 111). Diğer Şafi'i tabakât müelliflerinden el-Vâsıtî (ö.772/1370), İnbü’l-Mülakkın (ö. 804/1401) ve İbn Kâdî Şühbe (ö. 851/1448) de aynı tarihi verirler. (el-A’sam, 1998, s.176; İbnü'l-Mülakkın, 1997, s. 116; İbn Kâdî Şühbe, h. 1407, s. 1: 293). Daha sonraki dönemlerde biyografik bilgi aktaran kaynaklar Gazâlî'nin doğum tarihini h. 450/1058 olarak muhafaza etmişlerdir. Gazâlî’ye yakın kaynaklarda da fazla itibara alınmayan h. 451 y1lı sonraki dönemlerde de zikre değer görülmemiştir.

Gazâlî'nin biyografisine yer veren modern kaynaklarda tespit edebildiğimiz kadarıyla Gazâlî’nin doğum tarihi üzerinde klasik kaynakların verdiği tarihe ekseriyetle itimat edilmiştir. Ancak, Gazâlî’nin hayatı ve eserleri hakkında ilk modern araştırmayı yapanlardan biri olan Alman şarkiyatçı R. Gosche (ö.1889), Gazâlî’nin doğum tarihi ile ilgili sadece h. 451/1059 tarihini vererek klasik kaynakların ittifak ettikleri h. 450 tarihine itibar etmemiştir. (Gosche, 1858, s. 247). Hilmi Z. Ülken de benzer şekilde klasik kaynaklara muhalefet ederek Gazâlî’nin doğum tarihini m. 1055 olarak vermiş̧ir. (Ülken, 2004, s. 214.) Sıddık Hasan Han el-Kannevcî (ö. 1890), h. 451 tarihinde doğduğunun söylendiğini aktarmıştır. (elKannevcî, 2002, s. 630). Goldziher (ö.1921), Gazâlî’nin doğum tarihini h. 451/1059-60 olarak vermiştir. Goldziher, 1993, s. 68). DIA'daki "Gazzâlî" maddesini kaleme alan Mustafa Çağrıc1, "451/1059 yılında doğduğuna dair bir kayıt bulunmaktaysa da bu bilgi itimada şayan görülmemektedir." ifadesine yer vermiştir. (Çağrıcı, 1996. 13/489). Ancak Frank Griffel, Gazâlî'nin Felsefî Kelâmı adlı çalışmasının 
girişinde Gazâlî’nin biyografisi hakkında sunduğu kapsamlı araştırmada Gazâlî’nin doğum tarihi hakkında üzerinde ittifak edilen gerek h. 450/1058 ve gerek h. 451 tarihine itiraz eder. Griffel bu itirazını, Gazâlî’nin kendi ağzından ifade ettiği bazı tarihleri onun kesin bilinen ölüm tarihi ile karşılaştırarak farklı bir doğum tarihi tespitine gitmiştir. (Griffel, 2012, s. 51). Buna göre, Gazâlî, Rey ulemasından bazılarının onu birtakım fikirlerinden dolayı dönemin Horasan emir nâibi Sencer'e şikâyet etmelerinden dolayı Sencer'e bir müdafaa mektubu yazmıştır. Gazâlî, bu mektubu yazdığında elli üç yaşında olduğunu belirtir. Ayrıca mektupta Gazâlî, el-Halil'de Hz. İbrahim'in kabri başında yaptığı bir yemine de atıfta bulunur. Bu yeminde Gazâlî, hiçbir yöneticinin huzuruna çıkmayacağına ve hiçbir sultanın malından asla almayacağına, onlarla bu hususlarda bir münazaraya girmeyeceğine dair Allah'a söz vermiştir. Gazâlî, mektupta bu yeminini on iki yıl tuttuğunu da belirtir. (Yakûbî, 2017, s. 15). Gazâlî, Selçuklu veziri Nizâmüddîn Ahmed'e yazdığı diğer bir mektupta el-Halil'de yaptığı yeminin tarihinin ise h. 489/1096 y1lında olduğunu beyan etmiştir. (Yakûbî, 2017, s. 76). Griffel, bu tarihlerin ve Gazâlî’nin yeminini on iki sene tutmasının nasıl anlaşılması gerektiğini tartışmaya açmıştır. Gazâlî’nin kendisi hakkında "o bu yemini on iki sene tuttu." ifadesi iki şekilde anlaşılabilir: En kesin şekliyle elHalil'de yaptığı yemin ile Sencer'e yazdığı mektup arasındaki süredir. Buna göre bu süre Gazâlî’nin Nişabur'daki Nizamiye Medresesi'nde tekrar ders vermeye başladığ 1 499/1106 tarihinden iki sene sonrasına tekabül eder ki bu tarih h. 501/1108'dir. (Griffel, 2012, s. 51). Bu tarihte elli üç yaşında olduğunu Sencer'e yazdığı mektupta belirttiğine göre kesin bilinen vefat tarihi olan 505/1111 yılında Gazâlî’nin elli yedi yaşında olması gerekir ki bu da onun doğum tarihini kaynaklarda belirtilen $h$ 450/1058'den iki sene öncesine çekilmesi gerektiğine işaret eder. Buna göre Gazâlî, 448/1056-57 tarihinde doğmuş olmalıdır. Giriffel, klasik İslam medeniyetinde insanların yaşının mevsimlere uygun olarak güneş yılına göre hesaplandığını belirterek buna göre hesaplandığında Gazâlî’nin doğumunun bir sene daha geriye gideceğini ve h. 447/1055 olabileceğini ancak Gazâlî’nin eserlerinde verdiği tarihlerde ay takvimini esas aldığı bilinmekte olduğundan bu ihtimalin itimada şayan olmadığını belirtmiştir. (Griffel, 2012, s. 52).

Griffel, Gazâlî’nin yeminini on iki sene tutmasının zayıf da olsa diğer bir şekilde anlaşılabileceğini de belirtir. Buna göre Gazâlî'nin yeminini tutmaya başlaması el-Halil'de yemin ettiği tarihten bir yıl önce Bağdat Nizamiye Medresesi'nde ders vermeyi bıraktığı tarihten itibaren başlamış olabilir. Bu ihtimale göre Gazâlî’nin doğum tarihi 446/1054-55 tarihine tekabül eder. Sonuç olarak Griffel, Gazâlî’nin doğum tarihini hâlihazırda literatürlerde gözüken tarihten iki sene önce 448/1056-57 tarihlerinde olması gerektiğini ifade eder. Diğer yandan 446/1054 ile 448/1057 tarihleri Gazâlî'nin kendi otobiyografisi olan el-Munkız min'd-Dalâl' da verdiği bilgilerle de örtüşmektedir. (Griffel, 2012, s. 5253).

Griffel, Gazâlî’nin Bağdat'ı terk etmesinin arkasında yatan sebebin Müslümanların hayatında kırk yaşına geldiklerinde kazanmaya çalıştıkları manevi olgunluğun bir etkisi olabileceğini belirtir. Griffel, "kırk yaşına gelince bir insanın hayatında büyük değişimler yaşanması, Müslümanların biyografisinde tekrarlanan bir motiftir ve şayet bu motif Gazâlî'nin hayatında da kullanıldıysa onun 448/1056 tarihi civarında doğmuş olduğu yönündeki görüşümüz onaylanmış olur." (Griffel, 2012, s. 81) ifadelerine yer verir. Bu varsayıma göre Gazâlî kırk yaşına geldiğinde hâlâ arzu edilen bir Müslüman karakterine ulaşamadığı için manevi bir buhrana kapılmış ve neticede sırf erdemli bir Müslüman olabilmek için Bağdat'taki ihtişamlı hayatını terk etmiştir. Gazâlî'nin Bağdat'ı terk etmeden önce yaşamış olduğu krizin kırk yaş olgunluğuna ulaşamama endişesini andıran motifler için bkz., (el-Gazâli, 1416, s. 553). $\mathrm{Bu}$ tarihte kırk yaşında olduğuna göre doğum tarihi de h. 448/1056 civarında olmalıdır.

Griffel Gazâlî’nin doğum yılı ile ilgili öne sürdüğü tarihi vesikalara itimat ediyor olsa gerek ki, Gazâlî hakkında yazdığı eserlerde klasik ve modern kaynakların ittifak ettiği h. 450/1058 tarihini kullanmamış bunun yerine kendi tespit ettiği yaklaşık h. 448/1056 tarihini (Griffel, 2012, s. 51) veya bu 
tarihin güneş takvimi hesaplamasına göre tekabül ettiği h. 447/1056 y1lını kullanmıştır. (Griffel, 2017, s.192). Yine Stanford Encyclopedia of Philosophy'nin “al-Ghazali” maddesinde de Griffel, Gazâlî'nin doğum tarihini kendi tespit ettiği m.1056 senesi olarak kayda geçmektedir. (Griffel, https://plato.stanford.edu/entries/al-ghazali/, (Erişim, 13/01/2021). Griffel'in bu tespiti ikna edici olsa gerek ki, İslam Düşünce Atlası'nda Gazâlî’nin doğum tarihi h. 448/1056 olarak tarihlendirilmiştir. (Kaya, 2017, 2/529).

\section{Gazâlî’nin Doğum Yeri}

Gazâlî'nin doğum yeri bugünkü İran'ın Tahran'dan sonra en büyük ikinci şehri olan Meşhed'tir. Meşhed, İslam öncesine ait bir şehir olan Tûs’un yerini almıştır. (Öz, 2004, s. 29/363; Streck, 1979, s. 8/145). Tûs ise bu günkü Meşhed'in de içinde olduğu Râdkân, Tâberân, Bezdgûr, Nûkan kasabalarından meydana gelen Horasan bölgesindeki bir şehirdir. (el-İstahrî, 2004, s. 257; İbn Havkal, 2017, s. 373; elHamevî, 1995, s. 4/49; el-Kazvînî, ts., s. 411). Tûs aslında Gazâlî’nin doğduğu şehir değil, Gazâlî’nin doğum yeri olan Tâberân'ı da içine alan bölgenin adıdır. Meşhed ise Nûkan kasabasındaki Senâbaz köyünde metfun olan Şiîlerin sekizinci imamı Ali er-Rızâ'nın (ö. 203/818) hatırasını yaşatmak için bu ismi almıştır. Ali er-Rızâ'nın buraya defnedilmesinden sonra bu bölge Tûs olarak değil de Meşhed olarak meşhur olmaya başlamıştır. (Kılavuz, 1989, s.2/ 437). Anlaşılan o ki Meşhed, Senâbaz köyünün olduğu yerin yeni ismi olarak anılmaya başlamıştır. H. 791/1389 tarihinde Timur'un oğullarından Mîranşah'ın Tûs'u istilâ edip şehri tamamen harap etmesinden sonra Meşhed eski Tûs bölgesinin adı olarak daha geniş̧ bir coğrafya için kullanılmaya başlamıştır. (Streck, 1979, s. 8/147). Gazâlî’nin doğum yeri olan Tâberân, Tûs sınırları içerisinde olduğuna göre Timur orduları tarafından harabeye çevrilmiş bölgenin içerisinde kalmaktadır. Tûs'un yıkıma uğramasından sonra Meşhed Gazâlî’nin memleketi olarak da anılmaya başlamıştır. "Meşhed" ismi her ne kadar Gazâlî zamanında kullanılıyor olsa da Gazâlî, Şiîlik propagandası endişesiyle bu ismi hiç kullanmamıştır. (Griffel, 2012, s. 54).

Gazâlî’nin doğum yerinin Tus'a bağlı Gazâle isminde bir köy olduğu yönünde bazı iddialar da Gazâlî̀nin biyografisini tartışan eserlerde yer almaktadır. Klasik kaynaklardan Gazâlî dönemine en yakın olanlarda Gazâlî’nin doğum yerinin Gazâle köyü olduğuna dair net bir ifade yer almamaktadır. Gazâlî'nin Gazâle köyü ile ilişkilendirilmesi onun ismindeki nispetin "Gazzâlî"” şeklinde çift z ile mi yoksa "Gazâlî" şeklinde tek z ile mi telaffuz edileceği ile ilgili tartışmalar sebebiyle gündeme gelmiştir. Bu tartışma da Gazâlî'den yaklaşık bir buçuk asır sonra başlamıştır. Gazâlî’nin Gazâle köyüne nispet edildiğini ilk aktaran Iraklı İbnü'l Esîr'dir (ö. 630/1233). İbnül'l-Esîr, her ne kadar meşhur kullanıma aykırı olsa da bazılarının Gazâlî’nin ismindeki nispeti Tûs'a bağlı Gazâle köyüne nispetle "Gazâlî" tek z'li söylediklerini aktarır. (İbnü'l-Esîr, 1980, s. 2/379). İbnü'l-Esîr'in çağdaş1 tarihçi İbnü'l-Müstevfî de (ö. 637/1239) Gazâlî'nin Tûs'a bağlı Gazâle köyüne nispet edildiğini aktarır. (İbnü'l-Müstevfî, 1980, 1/34). Daha sonraki klasik kaynaklarda Gazâlî’nin Gazâle köyü ile ilişkilendirilmesi onun ismindeki nispetin kullanımının nasıl olması gerektiği ile ilgili tartışmada gündeme gelmiştir. Gazâlî’nin eserleri üzerine hacimli şerhler yazan Nevevî (ö. 676(1277), tarihçi İbn Hallikân (ö. 681/1282), Zehebî (ö.748/1348) ve Arap dil bilgini Feyyûmî (ö. 770/1368-69) gibi Gazâlî biyografisi aktaran âlimler Gazâlî’nin isminin kullanımındaki telaffuzla ilgili ihtilaf hakkında konuşurken Gazâlî’nin Gazâle köyüne nispetinden bahsetmişlerdir. (en-Nevevî, 1994, s. 215; İbn Hallikân, 1978, 1/98); ez-Zehebî, 2006, s. 14/278; el-Feyyûmî, ts, s. 2/446). Yemenli tarihçi el-Cündî (ö.732/1332) ise Gazâlî’nin doğum yerinin Gazâle köyü olduğu için "Gazâlî" nispetiyle meşhur olduğunu belirtir. (el-Yümmî, 1995, s. 2/349). 
Modern kaynaklarda ise Gazâlî’nin doğum yerinin Tûs'a bağlı bir kasaba/köy olan Gazâle olduğu söylemi onun ismindeki nispetten bağımsız bir şekilde dillendirildiği gibi klasik kaynaklarda tartışılan ismindeki nispetle bağlantılı bir şekilde de zikredilmiştir. Murtezâ ez-Zebîdî, (ö. 1205/1790) Tâcü'lArûs isimli Arapça sözlüğünde Gazâle'nin Gazâlî’nin mensup olduğu köy olduğunu belirtmiştir. (Zebîdî, ts., s. 30/97). Şemseddin Sâmî (ö. 1904), biyografi, tarih ve coğrafya ansiklopedisi Kâmûsü'lA'lâm'da Gazâlî'nin Tûs'a bağlı Gazâle köyünde doğduğunu söyler. (Şemseddin Sâmi, 1896, 5/3277). Hadîkatü'l-Evliyâ isimli eseriyle bilinen Hocazâde Ahmed Hilmi de (ö. 1914) aynı kanaati aktarır. (Hocazâde Ahmed Hilmi h. 1322, s. 5). Arap mütefekkir Mustafa Cevâd (ö. 1969) Gazâlî’nin Horasan bölgesindeki Tûs Şehrinin bir köyü olan Gazâle'de doğduğuna dair bazı rivayetler olduğunu söyler. (Mustafa Cevâd, 1961, s. 495). Hüseyin Emîn (ö. 2013) de Mustafa Cevâd'in Gazâlî'nin doğum yerinin Gazâle olduğunu düşündüğünü ve kendisinin de aynı görüşte olduğunu belirtmiştir. (Hüseyin Emîn, 1963, s. 28). Tûs şehrinin bin civarında köye sahip olduğu; Gazâle köyünün de Gazâlî’nin doğduğu köy olduğunu aktaran kaynaklar da bulunmaktadır. (Nureddin Ebû Lihye, 2016, s. 20). Rizâeddin b. Fahreddin (ö. 1936) Gazâlî -tek z'li- nispetinin Gazâlî’nin Gazâle köyünde doğduğu için verildiğini belirtir. (Rizâeddin b. Fahreddin, 2018, s. 19). Mehmet Ali Aynî (ö. 1945), Bernard Carra de Vaux'tan (ö. 1953) bazı değişikliklerle çevirdiği eserinde Gazâlî̀nin ebeveyninin Tûs'a bağlı Gazâle köyünden olduklarını ifade ederek Gazâlî̀nin doğum yerinin Gazâle olduğunu ima etmiştir. (Mehmet Ali Aynî, 2013), 41). Ahmed Davutoğlu (ö. 1983), Muhammed Ali Sallâbî, Mustafa Çağrıcı gibi düşünürler de Gazâlî’nin doğum yerinin Gazâle köyü olduğuna kanaat getirenlerdendir. (Davutoğlu, ts., s. 1/1; Muhammed Ali Sallâbî, 2017, s. 9; Çağrıc1, 2016, s. 20).

Gazâlî biyografisi sunan Batılı kaynaklarda da Gazâlî’nin doğum yerini Gazâle köyü olarak kaydeden önemli kaynaklar mevcuttur. Gazâlî’nin biyografisini ilk sunan modern kaynağın sahibi R. Gosche, Gazâlî'nin Tûs yakınlarındaki Gazâle köyünde doğduğunu sarahaten beyan eder. (Gosche, 1858, s. 247). Yine, diğer bir Batılı oryantalist M. S. G. Hodgson (ö. 1968) Gazâlî’nin doğum yerini Tûs yakınlarında bir köy olarak belirtir. Hodgson, 2020, s. 2/213). Onun ismini zikretmediği bu köy Gazâle olsa gerek. Henry Corbin (ö. 1978) Gazâlî’nin Tûs yakınlarındaki Gazâle kasabasında doğmuş olduğunu ifade eder. (Corbin, 2015, s. 318). Gazâlî üzerine kapsamlı bir araştırma yayımlayan W. M. Watt (ö. 2006), "Gazâlî" kelimesinin Tûs şehrinde sadece Gazâlî ile ilişkilendirilmesi sebebi ile hakkında bilgi bulunan Gazâle köyüne mensup bir adam anlamına geldiğini kaydeder. (Watt, 2003, s. 28).

Modern kaynakların Gazâlî’nin doğum yerini Gazâle köyü olarak göstermeleri, klasik kaynaklarda Gazâlî̀nin isminin nasıl telaffuz edileceğine dair üretilen teorilerden hareketle verilmiş bir hüküm olduğu göze çarpmaktadır. Modern kaynaklardaki bilgiler, klasik kaynaklarda Gazâlî’nin doğum yeri olabilecek Gazâle köyünün üzerindeki gizemi kaldırmamaktadır.

\section{Gazâlî’nin Soyu/Irkı}

Gazâlî’nin soyunun hangi millete/rrka mensup olduğuna dair klasik kaynaklarda bir bilgiye rastlanılmamaktadır. Onun soyu ile ilgili modern kaynaklar bazı cılız bilgiler aktarmakta ise de bu bilgilerin çoğu güvenilir vesikalara itimat etmemektedir. Klasik kaynaklarda âlimlerin kimlikleri zaman zaman onların ait oldukları ırka, millete nispetle zikredilmiştir. Gazâlî’nin ne isminde ne biyografisinde ırkını, milliyetini belirleyecek bir bilgi bulunmamaktadır. Irk ve milliyetin kişilerin ve toplumların sosyal statü ve kimliklerini belirlemede önemli bir etken olmaya başladığı modern çağın entelektüel birikimi, toplumu siyaseti ve dini etkileyen önemli şahsiyetleri ırk ve milliyeti üzerinden tartışmaya başlamıştır. Bu sebeple Gazâlî’nin ırkı ile ilgili tartışmalar modern kaynaklarda yer almaktadır.

Ali Muavvız ve Adil Abdülmevcûd, Gazâlî’nin el-Vecîz'inin tahkikli neşrine yazdıkları mukaddimede muhakkiklerin Gazâlî’nin soyu hakkında ihtilaf edildiğini belirtirler. Bazılarına göre Gazâlî, ataları İslam fethi zamanlarında İran topraklarına gelen köklü bir Arap ırkına mensuptur; 
bazılarına göre ise o Fars asıllıdır. (Ali Muavvız, Adil Abdülmevcûd, 1997, s. 1/10). Çağrıcı, DİA'daki "Gazâlî" maddesinde Gazâlî’nin Fars asıllı olduğunun sanıldığını aktarır. (Çağrıcı, 1996, s.13/489; a. mlf, 2016, s. 20). Gerhard Böwering, Encyclopaedia Iranica'da Gâzâlî̀yi tanıtırken "A man of Persian descentl Fars asıllı bir adam." diyerek onun İran asıllı olduğunu ihsas etmiş̦tir. (Böwering, 2001, s. 10/358). Hollanda asıllı Amerikalı şarkiyatçı Samuel Marinus Zwmer (ö. 1952) de Gazâlî’nin Fars asıllı olduğunu söyler. (Zwemer, 1923, s. 30). Avrasya ve Orta Asya uzmanı S. Frederic Starr, tamamı olmasa da Batılı kaynakların çoğunun İbn-i Sinâ, Harezmî, Farâbî ve Gazâlî gibi Orta Asyalı âlimleri Arap olarak tanıttıklarını ancak bunun fahiş bir hata olduğunu belirterek Gazâlî’nin Arap olmadığını vurgular. "Ingilizce bir kitap kaleme alan Japon ne kadar İngiliz ise bin sene evvel eserini Arapça yazan bir Orta Asyalı da o kadar Arap'tı. Yukarıda bahsedilen yazar ve düşünürlerin çoğu hayatlarını Arapça konuşan bir çevrede geçirmişlerdi ama ana dilleri Arapça değildi. Kaldı ki Arap da değillerdi." ifadelerini kullanan Srarr, birkaç istisna hariç hem dinî hem de fennî ilimlerde etkin olan Müslüman düşünürlerin çoğunun Arap olmadığı gerçeğinin dillendirildiğini aktarır. (Starr, 2020, s. 58). Starr'ın buradaki değerlendirmesi hatalıdır. Star bu yargısını atıf yaptığı eserlerin isimlerinden hareketle vermiş gibi gözükmektedir. Zira, Peter Adamson ve Richard C. Taylor'un editörlüğünde kaleme alınan The Cambridge Companion to Arabic Philosophy adlı eser her ne kadar isminden hareketle "Arap Felsefesi" gibi algilansa da editörler eserin girişinde İslam felsefesinin Yunanca düşüncenin Arap diline tercüme edilmesiyle başladığını ve İslam felsefesinin bir Arap felsefesi olmadığını, haddizatında bu felsefenin öne çıkan simalarının da Arap olmadıklarını belirtirler. (Adamson ve Taylor, 2018, s.3). Anlaşılan o ki, İslam Felsefesine Arap felsefesi isminin verilmesi sadece dilsel bir tanımlamadır. İslam filozofların Arap olup olmaması ile bir alakası yoktur. Gazâlî’nin mistik yönü üzerine eserler veren Margaret Smith da (ö. 1970), Gazâlî’nin her ne kadar eserlerini Arapça yazmış olsa da kendisinin Arap değil Fars asıllı olduğunu dile getirir. (Smith, 1983, s. 10). Kenneth Garden, Gazâlî'den "İranlı meşhur din adamı, düşünür" diyerek bahseder. (Garden, 2019, s.11). Muasır Arap düşünürlerinden Misırlı tarihçi Ahmed Ferîd Rufâî (ö.1957), (Ahmed Ferîd Rufâî, 1936, s. 1/79), felsefeci Tâhâ Abdülbakî Sürur (ö. 1969) (Abdülbakî Sürur, 1940, s. 12), Libyalı düşünür Muhammed Abdurrahman Merhabâ (ö. 2006), (Abdurrahman Merhabâ, 1993, s. 325), Hanna el-Fâhurî (ö. 2011) ve Halil el-Cerr de Gazâlî’nin Fars asıllı olduğunu belirtirmişlerdir. (el-Fâhurî, el-Cerr, 1993, 2:238). Diğer bir Misırlı düşünür Zeki Mübarek (ö. 1952), Gazâlı̂'nin soyu hakkında "her ne kadar tarihi kayıtlar ehemmiyet vermese de Gazâlî'nin soyu Fars asıllı bir aileden gelmektedir." (Zeki Mübarek, 2012, s.55) ifadelerini kullanır. Nureddin Ebû Lıhye ise Gazâlı̂’nin Fars asıllı olduğunu, Arap olamayacağını iddia eder: Zira Arap olmuş olsa idi o zamanki insanların adeti olduğu üzere Acem/Fars (Arap olmayan) topraklarında ikamet eden Arapların mensup oldukları kabile ismi ile anıldıkları gibi Gazâlı̂ de kabile ismi ile anılması gerekirdi. (Ebû Lıhye, 2016, s.21) der. İranlı muasır İslam düşünürü Seyyid Hüseyin Nasr da Gazâlî’nin Fars/İran kökenli olduğunu savunur. (Nasr, 1991, s. 12). Suriyeli İsmailî düşünür Ârif Tâmir (ö.1988) Gazâlî’nin ailesinin ve ecdadının isimlerinden hareketle Gazâlî’nin soyunun Müslüman Arap olduğunu ve dedelerinin bilinmeyen bir tarihte Arap topraklarından Fars memleketine hicret etmiş olduklarını iddia eder. (Tâmir, 1987, s. 44). Gazâlî'nin Şifâü'l-Ğalîl adlı eserinin tahkikli neşrini yapan Hamid elKebîsi de Tamir'in iddiaların aynısını dile getirmekle beraber Gazâlî'nin aslının kesin olarak tespit edilemediğini belirtir. (el-Kebisî, Nasr, 1971, s. 10).

M. Reşid Rıza (ö. 1935), Gazâlî’nin soyu ile ilgi el-Menâr dergisinde uzunca bir tartışmaya yer vermiştir. Reşid Rıza, önce Gazâlî’nin soyu ile ilgili iki ihtimali aktarır; buna göre, Gazâlî’nin soyu İslam fetihlerinin ilk dönemlerinde Fars coğrafyasına galebe etmiş Müslüman Araplara dayanmaktadır. Diğer ihtimale göre ise Gazâlî̀nin soyu Fars asıllıdır; İslam'la olan derin bağları sebebiyle isimleri Arapçalaşmıştır. Reşid Rızâ, Fars bölgesinde neşet eden ulemâ hakkında konuşan tarihçilerin çoğunun bu âlimleri Fars asıllı olarak kabul ettiklerini belirtir. Hatta bu tarihçiler Arap asıllı olduğu kesin olarak bilinen bazı âlimleri bile Fars asıllı olarak göstermektedirler. Bunun temel sebebi ise İbn Haldûn'un (ö.808/1406) ortaya attığı tezdir. (Rızâ, 1907, s. 502). İbn Haldun, "çok nadir istisnalar dı̧̧ında gerek şerî ilimlerde gerekse aklî ilimlerde İslam dininin bünyesinde yetişmiş âlimler ekseriyetle Acem yani 
gayr-i Araptır." şeklinde etnik yargıda bulunmaktadır. (İbn Haldûn, 2004, s. 2/994). Reşid Rızâ, bu hükmün kendisinin de ortaya atılan illetinin de hatalı olduğunu savunur. İslam âlimlerinden İster Acem topraklarında ister Arap beldelerinde yetişsin Arap olanlar olduğu gibi Fars asıllı olanlar da vardır. Bazılarının ise soyu kesin olarak tespit edilememiştir ki Gazâlî de bunlardandır. (Rızâ, 1907, s. 502). Bununla beraber R. Rızâ Gazâlî’nin anadilini muhafaza etmiş Arap soyundan geldiğini delillendirmeye çalışır. R. Rızâ bu çabasını Gazâlî’nin çağdaşı olan Abdülğâfir el-Fârisî'nin Gazâlî hakkındaki bir anekdotuna dayandırmıştır. el-Fârisî, Gazâlî'nin hayatını anlatırken onun Arap edebiyatının en seçkin ediplerinin bile hayrete düştüğü metinler kaleme aldığını söyler. Bununla beraber bu metinlerde bazı dilbilgisi/sarf-nahiv hatalarının bulunduğunu bu sebeple de eleştirilere maruz kaldığını aktarır. Gazâlî, bu eleştirileri Arap dilbilgisi eğitimi almadığını, Arapçadan sadece kendisine yetecek kadar eğitimle yetindiğini ifade ederek savuşturur. (el-Fârisî, h. 1382, s. 449). el-Fârîsî'nin bu tarihi kaydını tahlil eden R. Rızâ, Gazâlî’nin derinlikli bir Arap dili eğitimi almadığı halde akranlarına nazaran son derece beliğ eserler kaleme almasının ancak doğuştan gelen fasih bir Arapça yeteneğinin ürünü olabileceğini iddia eder. Beliğ bir üslup ve fasih bir ifade yeteneğinin Arap asılll olmayan Acemlerde derin bir dilbilgisi eğitimi almadan elde edilemeyeceğini söyleyen R. Rizâ, kendisinin de Arap dili eğitimi almadan önce Gazâlî'nin İhyâsı'nı okuyup anladığını söyler. Gazâlî’nin bu yeteneğinin Onun asli lisanını muhafaza eden Arap soyundan geldiğinin ispatı olacağını belirtir. (Rızâ, 1907, s. 502). Bununla beraber Gazâlî'nin Farsça bildiğini ve Farsça eserler telif ettiğini söyleyen R. Rızâ, Gazâlî’nin Fars asıllı olmuş olsa eğitim almadan Arapça beyan ve üslubunda beliğ ve fasih olamayacağını iddialarına ekleyerek onun Araplığını ispata çalışmıştır. (Rızâ, 1907, s. 505).

Ahmet Şerbasî Gazâlî’nin soyu ile ilgili itimat edilecek sağlam bir delil olmadığı için onun soyunu tespitin imkânsız olduğunu belirterek Gazâlî’nin Farslı olmasının onun için bir eksiklik olmayacağı gibi Arap ırkına dayanan bir soya müntesip olmasının da gayret ve himmetleriyle İslam'a yaptığı hizmetlerle elde ettiği şöhret ve saygınlığı artırmayacağını belirtir. (Der' ve el-Cemîlî, 2005, s. 29).

\section{Gazâlî’nin İsmi}

Gazâlî’nin ismi Muhammed'dir. Klasik kaynaklarda Gazâlî’ye nispetle en erken Gazâlî biyografisi sunan el-Fârisî, Gazâlî'nin ismiyle beraber babası ve dedesinin ismini zikreder; Muhammed b. Muhammed b. Muhammed. (el-Fârisî, h. 1382, s. 440) Gazâlî’den sonraki bir buçuk asır zarfında Gazâlî biyografisi veren eserlerde bu nesep zincir korunmuştur. İbn Asâkir, İbnü'l-Cevzî, Sem'ânî, Yâkut elHamevî, Sıbt İbnü'l-Cevzî gibi âlimler Gazâlî’nin ismini el-Fârisî’nin kullanımına mutabık bir şekilde vermişlerdir. Tespit edebildiğimiz kadarıyla Gazâlî'nin nesep zincirine ilk eklemeyi yapan İbnü'sSalâh'tır (ö. 643/1245). İbnü's-Salâh, Gazâlî'nin nesep zincirini dedesinin babası olan Ahmed isminde bir kişi daha ekleyerek verir. Muhammed b. Muhammed b. Muhammed b. Ahmed. (İbnü's-Salâh, 1992. s. 1/249). İbnü's-Salâh'tan sonraki kaynaklarda ise bu nesep zincirinin kullanıldığı görülmektedir. İbn Hallikân, Zehebî, Sübkî, İ̉nü'l-Mülakkın, İbnü'l-İmâd bu nesep zincirini kullananlardandır. İbü'sSalâh'ın Gazâlî'nin nesep zincirine Ahmed isminde bir kişiyi eklemesi ileride kendisinden bahsedilecek olan ve el-Gazâlî el-Kebîr olarak tanınan, İbnü's-Salâh'ın Gazâlî’nin amcası olarak tanıttığı kişiyle olan irtibatı sebebiyle olması gerekir. Kendisi hakkında detaylı bilgiyi ilk defa İbnü's-Salah'ın verdiği bu âlimin ismi Ahmed b. Muhammed'tir. (İsnevî, 2002, s. 2/114). Bu zat Gazâlî'nin amcası olduğuna göre Gazâlî’nin Ahmed isminde bir büyük dedesinin olması gerekir. Kaynaklarda Gazâlî’nin isminin sonuna doğduğu yere nispetle "et-Tûŝ̀", mensup olduğu mezhebe itibarla "eş-Şâfîi nispetlerinin eklendiği de görülmektedir.

Modern kaynaklarda ise Gazali'nin ismindeki nesep zinciri bazen kısaltmalar yapılarak olsa da klasik kaynaklarla büyük oranda mutabık olarak verilmektedir. Ancak, tespit edebildiğimiz kadarıyla M. Said Şeyh ve Margaret Smith Gazâlî'nin nesep zincirini verirken büyük dedesinin isminin başına "ibn Tâvûs/Tâ’us" eklemesi yapmaktadırlar. (Said Şeyh, 2014, 1/731; Smith, 1983, s. 9). Hilmi Ziya Ülken'in (ö.1974) ise Gazâlî’nin ismini “İbn Mehmed ibn Mehmed” (Ülken, 1946, s. 284) olarak 
zikretmesi, Muhammed isminin Arapça yazımıyla Mehmed isminin yazım karakterinin aynı olmasından kaynaklanan bir zühul eseri olmalıdır.

Gazâlî̀nin ismi hususunda tarih boyunca devam eden tartışma, onun "Gazâlî" nisbesinin etimolojisi etrafinda sürüp gitmiştir. Onun ismindeki nisbetin "Gazzâlî" çift z'li mi yaksa "Gazâlî" tek z'li mi olacağı hususunda klasik ve modern dönemin ilim insanları farklı teoriler ortaya atmışlarsa da net bir sonuca ulaşılmamıştır. Klasik kaynaklar her iki yazım şeklinin de doğruluğuna hak vermekle beraber bu hususta üç farklı ihtimali dile getirmişlerdir; a) Gazâlî’nin babasının mesleği olan gazzâl (iplikçi) mesleğine itibarla çift z'li nispet esas alınmalıdır. b) Tek z'li kullanım daha doğru olandır; Gazâlî’nin doğum yeri olan Gazâle köyüne nispetle. c) Yine tek z'li kullanım doğru olandır; Gazâlî’nin nesebine itibarla ki, Gazâlî, Ka'b el-Ahbâr'ın kızlarından biri olan Gazâle ismindeki bir kadının nesebine mensuptur.

Gazâlî’nin ismindeki nispetin yazım ve telaffuzu hakkındaki ilk tartışmayı Gazâlî’den bir asır sonra yaşayan İbnü'l-Esîr'in (ö. 630/1233) başlattığı anlaşılıyor. Bazı kaynaklarda Gazâlî'nin ismindeki nispetle ilgili tartışmanın Sem'ânî'nin el-Ensâb adlı eserinde olduğu izlenimi verecek şekilde Sem'ânî'ye atıf yapılmıştır. (Der' ve el-Cemîlî, 2005, s. 30; Nu'mânî, 2012, s. 34; Watt, 2003, s. 163). Sem'ânî'nin eserindeki dipnotta verilen bilgi Sem'ânî'ye değil eserin tahkikli neşrini hazırlayan Muhammed Avvâme'nin İbnü'l-Esîr'den naklettiği bir dipnot bilgisidir. (Sem'ânî, 1962, 9/140). Bu bilginin İbnü'l-Esîr'e ait olduğu İbnü'l-Esîr'in kendi ifadesinden de anlaş1lmaktadır; İbnü'l-Esîr, Sem'ânî'nin "ğazzâl" maddesi ile alakalı bilgi verdikten sonra "ben onun ihmal ettiği/unuttuğu hakkında derim..." ifadesi kullanarak Gazzâlî hakkında bilgi aktarır. (İbnü'l-Esîr, 1980, s. 2/379). Müsteşrik David Samuel Margoliouth'in (ö. 1940) yayımladığı el-Ensâb'ın tıpkıbasım neşrinde de Gazâlî hakkında herhangi bir bilgi bulunmamaktadır. (Sem'ânî, 1912, s. 408).

Zehebî'nin Siyeru A'lâmü'n-Nübelâ'sında Gazâlî biyografisi aktardığı pasajda Abdülgâfir elFârisi'ye dayandırdığı anekdotta her ne kadar Gazâlî’nin ismindeki nispet tartışması yer almasa da "Gazzâlî" (çift z'li) kullanımın geçerliliği hakkında daha geriye giden bir vesika bulunmaktadır. Bu kayıtta el-Fârisî, "Gazzâlî” teriminin attarî/koku satan, habbazî/fırıncı gibi bir sanat erbabını ifade eden kullanımlar olduğunu belirtmiştir. (Zehebî, 2006, s. 14:278). İbnü'l-Esîr, Sem'ânî'nin el-Ensâb adlı eserinin gözden geçirilerek tekrar düzenlenmiş hali olan el-Lübâb fì Tehzîbi'l-Ensâb adlı eserinde Gazâlî'nin nisbesinden bahsederken şöyle der: "Gazzâlî"” kelimesi, Hârizm ve Cürcân halkının

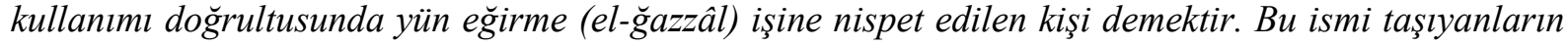
en meşhuru da Ebû Hâmid el-Gazzâlî'dir. Tûs'un köylerinden biri olan Gazâle'ye nispetle "Gazâlî" şeklinde tek z'li söyleyenleri de işittim; ancak bu meşhur kullanıma muhaliftir. (İbnü’l-Esîr 1980, s. 2/379). İbnü'l-Esîr'in tek z'li telaffuz için “bu meşhur kullanıma muhaliftir." ifadesi, o zamana kadar Gazâlî'nin ismindeki nispetin çift z'li olarak meşhur olduğu izlenimini vermektedir. İbnü'l-Esîr'den sonra en-Nevevî, İbnü'l-Esîr'in rivayet ettiği çift z'li kullanımın maruf/bilinen olduğunu söyler. (eşŞerkâvi, YE, vr. 127a). İbn Hallikân da (ö. 681/1282) aynı görüşü savunarak "Gazzâlî" (çift z'li) kullanımını tercih eder. (İbn Hallikân, 1978, s. 1/98). Şiî tarihçi İbnü't-Tıktaka'nın (ö. 709/1309'dan sonra) tercihi de çift z'li kullanımdır. (İbnü’t-Tıktaka, 1997, s. 151). Gazâlı̂’nin İhyâ' sına hacimli bir şerh yazan Zebîdî de Gazâlî’nin nisbesi hakkında tartışmaya yer veren Âlimlerden biridir. Zebîdî, "Gazzâlî (çift z'li) telaffuzun doğru olduğuna dair Gazâlı̂’ye yakın tarihlerde yaşayan Sem'ânî’den bir alıntı yapar. Sem'ânî Tûs halkına "Gazâle" ismindeki köyü sorduğunda böyle bir köy ismi tanımadıklarını söylediklerini aktarmıştır. Bu sebeple Gazâlî’nin Gazâle ismindeki köye nispet edilmesi doğru değildir; doğru telaffuz "iplikçilik sanatı ile uğraşan" anlamında "Gazzâlı̀" olmalıdır. Zaten Hârizm, Cürcân yöresindeki halkın adeti de bir takım sanat erbabını ifade etmek için kelimemin bu formunu kullanmaktır. (Zebîdî, 1994, 1/18). Tarihçi Zehebî (ö. 748/1348), İbnü'l-Esîr'den birkaç yıl sonra Gazâlî’nin fikıh eserlerine şerhler kaleme alan İbnü's-Salâh ve talebesi en-Nevevî'nin (ö. 
676/1277) Gazâlî’nin ismindeki nispeti taştıklarını aktarır. Zehebî, Nevevî'nin İbnü's-Salâh'tan aktardığı bir anekdotu okuduğunu duyurur. Bu kayda göre Gazâlî'nin bizzat kendisi ismindeki nispetin çift z'li değil tek z'li olması gerektiğini söyler. Gazâli talebelerinden biri olan İbnü'l-Hamîs el-Ka'bî'ye (ö. 552/1157) şöyle söyler: İnsanlar benim ismimi "Gazzâll’” (çift z'li) kullanıyorlar; halbuki ben Gazâle ismindeki köye mensubum ve İsmim "Gazâlî̀" (tek z'li) olmalıdır der. (Zehebî, 2006, s. 14/278). Ancak Zehebî, diğer bir eseri olan el-İber fi Tarihi men Ğaber isimli eserinde Gazâlî’nin ismindeki nispetin "Gazzâlî" (çift z'li) olması gerektiği yönünde bir tercih kullanır. (Zehebî, 1985), 2/388). Bu nisbenin tek z'li olması gerektiği yönündeki bir diğer iddiayı sözlük yazarı el-Feyyûmî dile getirir. elFeyyûmî, Sem'ânî'nin aksine Gazâle'nin Tûs'un bir köyü olduğunu iddia eder ve bu iddiasını Gazâlî'nin soyundan gelen birisinin beyanlarına dayandırır. Sittü'l-Münâ isminde Gazâlî'nin kızlarından birine nesep silsilesi dayanan Mecdüddîn b. Muhammed şöyle demektedir: Insanlar Atamız Gazâlî'nin ismini çift z ile telaffuz etmekle hata ediyorlar; halbuki Gazâlî Tus'a bağlı Gazâle köyüne nispetle tek z'li telaffuz edilmelidir. (Feyyûmî, ts. s. 2/446; Zebîdî, 1994, s. 1/18).

Gazâlî’nin ismindeki nispetin tek z ile telaffuzunun Gazâle ismindeki nenesinden dolayı olduğunu iddia edenler de vardır. Bu iddia ise Kâdî İyâz'ın (ö. h. 544/1149) eş-Şifâ adlı eserine şerh yazan Şahâbeddin el-Hafâcî’ye (ö. 1069/1659) aittir. el-Hafâcî, Gazâlî’nin ismindeki nispetin tek z'li olmasının diğer bir sebebinin Gazâlî'nin soyunun Ka'bü'l-Ahbâr'ın (ö. 32/652) Gazâle ismindeki bir kızına dayanması sebebiyle olduğunu aktarır. (el-Hafâcî, ts., s. 4/494). Zebîdî bu iddianın doğru olması halinde Gazâlî'nin ismindeki nispeti tartışmaya mahal olmayacağını belirtir. (Zebîdî, 1994, 1/18). Rizâeddin b. Fahreddin, Gazâlî'nin Ka'bü'l-Ahbâr'ın kızı'nın turunu olduğuna dair rivayetin aslının olmayacağını aktarır. (Fahreddin, 2018, s. 20). W. M. Watt da bunun daha az muhtemel olan olduğunu söyler. (Watt, 2003, s. 165).

Gazâlî’nin ismindeki nispetle ilgili dikkat çekici bir yorum son dönem Osmanlı âlimlerinden Mehmed Hafid Efendi'den (ö.1811) gelmiştir. Hafîd Efendi, galat terimler üzerine telif ettiği sözlükte "Gazzâlî” çift z'li nispetin Gazâlî’nin alemi olduğunu, "Gazâlî" tek z'li kullanım şeklinin ise çift z'li kullanımın galatı olduğunu söyler. Ancak Sem'ânî’nin aktardığı tek z'li nispetin bir kabilenin ismi olup bu kabileye nispetle tek z'li "Gazâlı”" şeklindeki değerlendirmenin ise galattan salim olacağını belirtir. (Mehmed Hafîd, 2018, s. 415).

Klasik kaynaklardaki bu tartışmada bir neticeye varılamadığı Sadefî’nin (ö. 776/1363) ifadeleriyle de tahkim edilmiş gözükmektedir. Sadefî, İki telaffuz şeklinin hangisinin doğru olduğunu en iyi Allah bilir diyerek her iki tercihin de delillerinin diğer tercihi göz ardı etmeye yetmeyeceği kanaatini izhar etmiştir. (Sadefî, 2000, s. 1/213).

Modern kaynaklarda da Gazâlî’nin ismindeki nispetin etimolojisi mevzubahis olmuş hatta bazı müstakil makalelere bile konu olmuştur. Mısırlı tarihçi Ahmet Teymur Paşa (ö. 1930) Zabtu'l-A'lâm'da bu konuda klasik tartışmaları aktarmış Mısır'da tek z'li kullanımın yaygın olduğunu belirtmekle beraber çift z'li kullanımın daha meşhur olduğunu ifade etmiş̧ir. Özellikle şairlerin kullanımında çift z'li imlanın çok yaygın olduğunu belirten A. Teymur Paşa, bu iddiasını birçok şiirden örnekler vererek desteklemiştir. (Ahmet Teymur Paşa, 1947, s. 110-112). Diğer bir Mısırlı çağdaş düşünür Muhammed İbrahim el-Feyyûmî (ö. 2006) klasik tartışmaları aktarmakla beraber “Gazâlı̂” (tek z'li) isimlendirmesinin Gazâlî'nin ailesinin lakabı olduğunu ve Gazâlî’den önce kullanıldığını vurgular. Gazâlî isimli diğer meşhur âlimler hakkında kısa bir bilgi aktaran el-Feyyûmî, çift z'li kullanımın sonradan Gazâlî’nin babasının mesleğinden esinlenerek tekit/mübalağa için kullanıldığını iddia eder. elFeyyûmî tek z'li kullanımın Mısır'da meşhur olduğunu da ifadelerine ekler. (el-Feyyûmî, ts., s. 23-25). Iraklı muasır düşünür Abdülemir el-A’sam, Ürdünlü tarihçi el-Azîzî'den (ö. 2004) Gazâlî’nin isminin çift z'li telaffuzunun yanlış olduğunu, doğru olanın Gazâle köyüne nispetle tek z'li olması gerektiğini aktarır. el-A'sam, kendi görüşünün ise çift z'li kullanımın doğru olduğu yönünde olduğunu belirtir. (el- 
A'sam, 1998, s. 27-28). Gerek el-Azîzî'nin gerekse el-A'sam'ın tercihleri Gazâlî'nin ismindeki nispetle ilgili tarihi kaynakların aktardığı bilgilerin daha tutarlı olanı tercih etmelerinden kaynaklıdır.

Modern İslami kaynaklarda Gazâlî’nin isminin nispetindeki değişimle ilgili farklı bir yorum da Gazâlî üzerine müstakil bir çalışma yayımlayan İranlı muasır düşünür Abdülhüseyin Zerrînkûb'dan (ö.1999) gelmiştir. Zerrînkûb, Gazâlî’nin İmamü'l-Haremeyn el-Cüveynî’nin (ö.478/1085) yanında talebe iken şöhret bularak parmakla gösterilen bir kişi olduğunu ve "Gazzâlî" diye çağrıldığını söyler. Gazâlî, isminin dostları tarafından babasının basit mesleğine nispetle "Gazzâlî" şekilde anılmasından hoşlanmaz. Yükselme arzusuna sahip tabiatı ve gençlik gururu incinen Gazâlî, kendisini Tûs çevresinde unutulmuş, kimsenin nerede olduğunu bilmediği bir köye, Gazâle’ye mensup göstererek isminin nispetini "Gazâlî” (tek z'li) şekilde söylenmesini istemiştir. (Zerrinkub, 2007, s. 53). Zerrinkub'un yorumuna göre Gazâlî bilinçli bir şekilde isminin tek z'li telaffuzunu talep etmiş ve bu talebini gerçekleştirmek için halihazırda mevcut olmayan veya eskiden var olup ancak unutulmuş bir köye kendisini nispet etmek istemiştir.

Gazâlî'nin ismindeki telaffuzla ilgili oryantalistlerin de bir hayli kafa yordukları ve müstakil makaleler kaleme aldıkları görülmektedir. Oryantalistlerden Gazâlî’nin biyografisi ile ilk ilgilenen, Osmanlı tarihi üzerine de uzman olan Avusturalyalı şarkiyatçı Joseph von Hammer'dir (ö. 1856). Hammer, Gazâlî'nin Eyyühe'l-Veled isimli risalesini ilk defa neşreden kişidir. O, bu risalenin Arapça neşriyle beraber Almanca tercümesini de yayımlamış, eserin ön sözünde Gazâlî’nin biyografisine yer vermiştir. Hammer, her ne kadar Gazâlî’nin ismindeki nispetin nasıl olacağına dair bir tartışmaya girmese de Gazâlî’nin babasının yün tüccarı (gazzâl) olduğunu bu sebeple de onun "Gazâlı̂” şeklinde anılır olduğundan bahseder. (Hammer-Purgstall, 1838, s. X). Ancak, bu durumda Gazâlî’nin nispeti çift z'li olması gerekirken Hammer tek z'li kullanımı tercih ettiği görülür. Gazâlî’nin ismi üzerine tartışmanın batılı kaynaklarda müstakil olarak tartışıldığı ilk kaynak ise İskoç şarkiyatçı D. B. Macdonald'ın (ö. 1943) The Name al-Ghazzâlı̂ isimli çalışmasıdır. Bu makalede Macdonald, çift z'li kullanımın delillerinin müzakeresini sunmakla beraber hangi kullanımın esas alınacağına dair bir karar vermez. (Macdonald, 1901, 18-22'den aktaran Watt, 2003, s. 163). Macdonald'in kendi tercihi ise çift z'li kullanımdır. Macdonald, 1899, s. 71-132). P. K. Hitti (ö. 1978), Gazâlî’nin babasının büyük babası gibi yün eğiricisi (gazzal) olduğunu ve "Gazzâlî”" isminin buradan kaldığını belirterek çift z'li okumanın daha doğru olduğunu söyleyenlerdendir. (Hitti, 2020, s. 584). Bununla beraber Hitti, "Gazâlî” formunun Gazâle ismindeki bir köyle ilişkili olduğunu ve bu ihtimalin de mümkün olabileceğini dile getirir. (Hitti, 1995, s. 178). Bu meseleyle alakalı müstakil çalışma yapan diğer bir şarkiyatçı ise İngiliz oryantalist W. M. Watt'tır. Watt, Gazâlî üzerine yazdığı Müslim Intellectual/Müslüman Aydın adlı eserinin sonunda Gazâlî’nin ismindeki nispetin imlasını tartıştığı bir ek koymuştur. Watt, bu nispetlerin hangi argümanlara dayanılarak üretildiğine dair tarihi kayıtların müzakeresini yaparak bir tercih ortaya koymaya çalışır. Watt, "Gazâlî" (tek z'li) telaffuzunun "difficilior lectio potius" (daha zor olanın tercih edilmesi) ilkesine göre kabul edilmesinin gerekli olduğunu savunarak "Gazâlı̀" (tek z'li) tercihinin lehinde üstün bir ihtimalin olduğunu vurgular. (Watt, 2003, s. 162-162). Bu tartışmaya son katılan batılı araştırmacı ise Gazâlî hakkında en otoriter aydın diyebileceğimiz, İslam Felsefesi üzerine yetkin çalı̧̧maları olan Alman akademisyen Frank Griffel'dir. Griffel, Gazâlî'nin isminin etimolojisi hakkında müstakil bir makale hazırladığı gibi Gazâlî’nin Felsefi Kelamı adlı kitabında da bu hususa değinmiştir. Griffel, tarihçilerin Gazâlî'nin isminin teleffuzu ile ilgili tartışmaya başladıkları zamanın, kesin bir bilgi edinmek için epey geç olduğunu, meseleye ilişkin yapılan iki zıt açıklamanın da meseleyi vuzuha kavuşturacak yeterliliğe sahip olmadığını savunur. (Griffel, 2013, s. 210). "Gazâlî" nisbesinin Gazâlî'den en az üç ya da dört kuşak önce Gazâlî sülalesi için kullanılan bir isim olduğunu belirten Griffel, bu nisbenin ilk önce neye izafetle kullanıldığını belirlemenin imkânsı olduğunu vurgular. Gazâlî tarafindan bizzat tercih edildiği aktarılan tek z'li kullanımın yanında çift z'li terkibin bu isme bir 
anlam kazandırmak için dilbilimcilerin teşebbüsüyle ortaya çıkmış olabileceğini dile getirir. Watt'in tek z'li telaffuz tercinin argümanını eleştiren Griffel, her iki yazım şeklinin eşit derecede mümkün olduğu için çekimser kalmanın doğru olduğunu, tek z'li imlanın ise -biraz ironik şekilde-emek ve mürekkep tasarrufundan dolayı tercihe şayan olduğunu söylemiştir. (Griffel, 2013, s. 210). Griffel, diğer bir çalışmasında ise "Gazzâlî" çift z'li etimolojinin daha makul olmasina rağmen bunun Gazâlî̀nin kendisinin tercih ettiği sadece tek z'li imlaya ilişkin bulgulara ters olduğunu kaydetmiştir. (Griffel, 2012, s.48).

Gazâlî, Orta Çağ Avrupa'sında Ebuhamet ve Algazel olarak isimlendirilmiştir. Goldziher, (1959, s.176) Modern dönem Avrupa'sında ise Gazâlî, Alghazali ve Algazzali olarak bilinmektedir.

\section{Gazâlî’nin Künyesi}

Kaynaklarda "Ebû Hâmid" olarak bilinen Gazâlî’nin künyesi hakkında da birtakım tartışmalar yapılmıştır. "Ebû Hâmid/ Hâmid'in babası" anlamındaki künyenin Gazâlî̀ye Hâmid isminde bir çocuğundan dolayı mı verildiği yoksa aynı künyeli bir akrabasından dolayı mı bu künyeyi kullandığı hususunda ihtilaf bulunmaktadır. Zwemer, Gazâlî’ye "Ebû Hâmid” künyesinin küçüklüğünde ölen Hâmid ismindeki oğluna istinaden çok sonradan verildiğini iddia eder. (Zwemer, 1923, s. 38). Bu iddia eldeki tarihi vesikalara ve o dönemdeki künye verme kültürüne dair bilgilere müracaat edildiğinde mesnetsiz gözükmektedir. İlk Gazâlî biyografisi aktaran el-Fârisi Gazâlî’nin ismini künyesiyle beraber vermektedir. (el-Fârisî, 1382, s. 83). Yine Gazâlî’nin çağdaş1 ve talebesi olan Ebû Bekir İbnü'l-Arabî (ö. 1148) kelam ve mezhepler tarihini konulu el-Avâsım mine'l-Kavâsım adlı esesinde Gazâlî'yi onun künyesini zikrederek "Ebû Hâmid" diye anar. (İbnü'l-Arabî, 1974, s. 12,16,24, vd). Bu kaynakların verdiği bilgiler Gazâlî’nin hayatında iken "Ebû Hâmid" künyesini kullandığını göstermektedir. Ayrıca o dönemde Horasanlı anne babaların yeni doğan çocuklarına ismiyle beraber bir künye verdikleri de dönemin isim koyma kültüründendir. (Zerrinkub, 2007, s. 25).

Klasik kaynaklarda Gazâlî’nin künyesini kime izafetle taşıdığına dair bir bilgi bulunmamakla beraber el-Fârîsî, onun sadece kızlarının olduğunu aktarmaktadır. (Sübkî, 1976, s. 5/211) el-Fârisî’nin Gazâlî̀nin sadece kızlarının olduğunu söylemekle beraber Gazâlî̀yi "Ebû Hâmid" künyesiyle zikretmesi onun bu künyeyi bir oğluna izafetle alması ihtimalini zayıflatmaktadır. Oğlu olduğuna itimat edebileceğimiz bazı rivayetler varsa da Gazâlî’ye bu künyenin kendi sülalesinden "Ebû Hâmid" lakaplı itibarlı bir akrabasının anısına verildiğine dair işaretler vardır. Gazâlî’nin âlimlere ve sufîlere düşkün olan babası, çocuklarına Gazâlî ailesinden daha önce yaşamış âlim akrabalarının künyesini vererek çocuklarının da yetişip âlim olmalarını istemiş olabilir. Gazâlî’nin kardeşi Ahmet'in künyesi de EbulFütûh'tur. (Sübkî, 1976, s. 6/60). Bu künyeyi de babası, sülalesinin geçmişindeki bir fâkihin anısına oğlu Ahmet için güzel bir talih olması dileği ile vermiştir. Zerrinkub'un yorumuna göre Gazâlî’nin babası, kendisinin elde edemediği fakîhlik makamına oğullarının erişmesini arzulamış; iyi bir talihe vesile olması için geçmişte âlim olan akrabalarının künyelerinden esinlenerek bu künyeleri çocuklarına vermiştir. (Zerrinkub, 2007, s. 24-25). Künyenin dönemin İslam geleneğinde bir kişinin saygınlığını ifade etmek için ismin yerine kullanılıyor olması, (İbn Manzûr, h.1414, s. 15/233). Gazâlî'nin "Ebû Hâmid" künyesini almasında da etkili olmuş gibi gözükmektedir. Gazâlî’nin babası geçmişte bir akrabasının elde ettiği şöhreti kendi soyundan bir evladının devam ettirmesini umarak bu akrabasının kullandığı künyeyi oğluna vermiştir. Bu kişi ise h. 435/1043-44'te vefat eden, el-Gazâlî el-Kebîr/elKadîm (Sübkî, 1976, s. 4/87) olarak bilinen Gazâlî'nin amcası fakîh Ebû Hâmid Ahmed İbn Muhammed el-Gazâlî̀'dir. (İsnevî, 2002, s. 2/114).

Modern kaynaklarda Gazâlî’nin "Ebû Hâmid” künyesini küçük yaşta vefat eden Hâmid ismindeki oğluna izafetle aldığını söyleyen kayıtlar bulunmaktadır. Abdurrahman Merhaba (ö. 2006) ve Süleyman Dünya (ö. 2010) bu iddiayı net bir şekilde dillendirir fakat herhangi bir kaynak göstermezler. (Merhaba, 1993, s. 330; Dünyâ, 1965, s. 22). Abdülemir el-A'sam (ö. 2019) de aynı görüştedir. (el-A’sam 1998, s. 
27). Ârif Tâmir de Gazâlî’nin kendisiyle künyelendiği Hâmid'in Gazâlî’nin ilk çocuğu olduğunu ve küçükken öldügünü söyler. (Tâmir, 1987, s.41). Bunların dışında Gazâlî’nin küçük yaşta vefat eden bir oğlu olduğunu söyleyen modern kaynaklar da vardır. (es-Sâmî, 1992, s. 45; Smith, 1983, s. 57). Çağrıc1 ise onun Hâmid isminde bir oğlunun olup olmadığının bilinmediğini eğer varsa küçük yaşta öldügünü söyler. (Çağrıc1, 1996, s. 13/530).

Gazâlî’nin "Ebû Hâmid" künyesini, ilmiyle temayüz etmiş olan "Hâmid" ismindeki amcasından aldığını söyleyen Hitti, onun küçük yaşta ölen bir çocuğunun olmadığını belirtir. (Hitti, 1995, s. 178). Klasik kaynaklar Gazâlî’nin meşhur bir akrabasından bahsetmektedir; fakat bu kişinin isminin Hâmid değil, Ahmed b. Muhammed olduğunu tasrih etmişlerdir. Aşağıda "Gazâlî̀nin Ailesi” başlığı altında da görüleceği üzere önceki Ğazâlî’nin künyesi de bizim meşhur Gazâlî’miz gibi Ebû Hâmid'dir. (Sübkî, 1976, s. 4/84, 89). Muhtemeldir ki, Gazâlî’nin babası çocuklarının kendi ailesindeki önceki âlimler gibi ilim, irfan sahibi olmalarını çok arzu etmesinden dolayı onların hem isimlerini hem de künyelerini evlatlarının hüsnü talihine vesile olması umuduyla yaşatmamak istemiştir.

Hatîb el-Bağdâdî'nin Târîhu Bağdad, isimli eserine zeyl yazan İbnü’n-Neccâr el-Bağdâdî (ö. 643/1245), diğer hiçbir eserde rastlamadığımız şekilde Gazâlî’nin künyesine bir ekleme yapar. Onun verdiği Gazâlî nesep zincirinde Gazâlî’nin künyesi olan Ebû Hâmid, "Ebû Hâmid b. Ebî Abdillah" şeklindedir. Bkz., (el-Bağdâdî, 2004, s. 21/27. Muhtemelen bu bir zühul veya istinsah hatasıdır.

\section{Gazâlî’nin Lakapları}

Gazâlî gerek hayatta iken gerek öldükten sonra birçok övgü dolu lakaplarla yad edilegelmiştir. Onu, daha hayatta iken zamanının devlet adamları, halifeleri ve ulemâsı birtakım lakaplarla yüceltmişler; Müslüman kültürüne yaptığ hizmetleri sebebiyle kendisine tevcih ettikleri övgü dolu vasıflarla taktir etmişlerdir. Onun herkes tarafından bilinen meşhur lakapları olduğu gibi; kendisi hakkında fikir beyan eden, hayatını yazan ve eserlerini tetkik edip şerh yazan birçok âlim onun hakkında farklı lakaplar kullanmışlardır. Kanaatimizce Gazâlî, Müslüman düşünürler içinde en fazla ve en abartılı lakaplarla anılan kişidir. Şeyh el-Ayderûs, (ö.1038/1628) İhyâ 'ü Ulûmiddîn'in faziletini ifade etmek üzere kaleme aldığı Ta'rifü'l-Ahyâ bi Fezâil'l-Ihyâ adlı eserin girişinde hem Gazâlî̀yi hem de İhyâ'yı çok abartılı diyebileceğimiz ifadelerle övmüş; Gazâlî̀yi "Mübînü'l-hılli ve'l-hürmeti” (helali ve haramı beyan eden) gibi lakaplarla anmıştır. (el-Ayderûsî, 1994, s. 1/2.3). İhyâa' ya Osmanlıca şerh yazan Yusuf Sıdkî elMardinî de (ö. 1903) eserinin mukaddimesinde Gazâlî’nin hâl tercümesini aktarırken yaklaşık yarım sayfaya yakın Gazâlî’yi övücü lakaplar zikretmiştir. (el-Mardînî, 2015, 1/28). Bazı âlimler de Gazâlî' yi, eserlerinin gerek çokluğu gerekse güvenilirliği hususunda adeta Hz. Peygamber'in (s.a.v) "Seyyidü'lenbiyâ" vasfiyla mukayese edercesine "Seyyidü’l-musannifîn" unvanına layık görmüşlerdir. (el-Yâfi ‘̂̀, 1997, s. 3/444).

Gazâlî daha hayatta iken kendisine bazı lakaplar tevcih edilmiştir. Onun Nizâmiye Medresesi'nde ders vermeye başladığı dönemler, devlet adamları tarafindan lakaplarla şöhret kazanmaya başladığ 1 zamanlara tekabül etmektedir. Gazâlî, her ne kadar ilk övgü dolu lakabı hocası el-Cüveynî'den (ö. 478/1085) almışsa da -el-Cüveynî Gazâlî’ yi “bahrun müğdikun/dolup taşan bir okyanus" olarak tavsif eder. (Sübkî, 1976, s. 6/196)- onun şöhretini ortaya koyan lakaplar devrinin önemli devlet adamı olan Selçuklu veziri Nizâmülmülk (ö. 485/1092) ve Abbasî halifesi el-Müstazhirî’nin (ö. 512/1118) verdiği lakaplardır. Gazâlî, Nizamülmülk tarafından Bağdat Nizamiye Medresesi’ve müderris olarak tayin edildiğinde Nizamülmülk ona "Zeynüddîn ve Şerefü'l-eimme" lakaplarını vermiştir. (İbnü'l-Cevzî, 1992, s. 16/292). Abbasî halifesi el-Müstazhir-Billah ise Gazâlî’ye "Huccetü’l-İslam” lakabını Bâtınilere karşı verdiği kültürel mücadeledeki başarısını taktir etmek için vermiştir. Bu lakap Nizamülmülk'ün verdiği lakapları geride bırakarak onun en meşhur unvanı olagelmiştir. "Huccetü'l- 
İslam ve "Zeynüddin” lakalarını Bâtınilere karşı yazmış olduğu Fedâihu'l-Bâtıniyye eseri sebebiyle aldığı söylenmektedir. Sünnî düşünceye yaptığı bu hizmet karşılığında halife el-Mustazhir-Billah ona bu unvanları vermiştir. (Acar, 2018, 6/474). Özellikle "Hüccetü'l-İslam" lakabının verilmesi, batınîliği tasfiye edip Sünnî İslam görüşünü tahkim etmesi neticesinde verildiği söylenir. (Gencer, 2015, s. 6:675). Gazâlî'ye hayatında iken birtakım lakaplarla hitap eden diğer bir devlet adamı da Irak veziri Ahmed b. Nizâmülmülk'tür (ö. 544/1150). O, Gazâlî'ye yazdığı bir mektupta Gazâlî'den "Hâce İmam Zeynüddîn, Huccetü'l-İslam, Ferîdüzzâman” diye bahseder. (Yakûbî, 2017, s. 68).

Gazâlî'den sonra ilk Gazâlî biyografisi sunan el-Fârisî, Gazâli’den "Huccetü'l-İ̀slam ve'lMüslimîn, İmâmü eimmetüddîn" lakaplarıyla bahseder. (Sarîfînî, 1362/1983, s. 83). Bize en geniş Gazâlî biyografisi nakleden Sübkî ise bu lakaplara "İmamülcelîl, Maheccetüddîn, Câmi'u eştâti'l-ulûm" gibi diğer bazı lakaplar ekler. Bunların dışında Gazâlî, “Âlimü'l-evhad, Cemâlü'l-firak, Müfti'l-ümme, Bereketü’l-enâm gibi diğer övgü dolu lakaplarla da tebcil edilmiştir. (Sübkî, 1976, s. 6/191).

Gazâlî'nin Huccetü'l-İslam/ İslam'ın otoritesi lakabını alması onun Bâtınîlere karş1 ortaya koyduğu Sünnî İslam mücadelesindeki başarısı sayesinde olduğu anlaşılmaktadır. Modern kaynaklarda ona "Huccetü'l-İslam" lakabının verilmesiyle ilgili farklı değerlendirilmeler yapılmaktadır. Corcî Zeydân (ö. 1914) Gazâlî’nin filozoflarla onların kendi yöntemlerini olan burhanla mücadele ve münazara ettiği için bu lakapla anıldığını söyler. (Zeydân, 2012, s. 461). Hitti, herhangi bir senet zikretmeksizin Gazâlî’nin bu unvanı üç yüz bin hadis ezberlemesi sayesinde aldığını iddia eder. (Hitti, 2020, s. 561). Ancak bu iddia temelsiz gibi gözükmektedir. "Huccet" hadis literatüründe mutekaddimîn âlimlerine göre hıfzettiği metinler ve senetler hususunda son derece güvenilir, rivayet ettiği hadisler delil olarak kullanılabilir olan muhaddistir. Müteahhirûna göre ise üç yüz bin hadisi ezberleyen bir muhaddise verilen unvandır. (Şemsüddîn ez-Zehebî, 1998, s. 1/3; el-Münâvî, h. 1318, s. 6). Diğer bir görüşe göre hüccet, sekiz yüz bin hadisi ravilerinin durumu ile birlikte bilen hadis âlimidir. (Aydın, 2012, s. 118). Gazâlî’nin böyle bir hadis kültürüne sahip olduğu veya bu kadar fazla hadis bildiğine dair herhangi tarihi bir kayda rastlanmamakla beraber Gazâlî̀nin kendisi hadis konusunda sermayesinin pek az olduğunu itiraf etmektedir. (Gazâlî, ts., s. 630).

\section{Gazâlî’nin Ailesi}

Gazâlî’nin ailesi ve akrabaları hakkında klasik kaynaklarda çok az bilgi yer almaktadır. Gazâlî’nin babasının adının Muhammed olduğu Gazâlî'nin nesep silsilesinden anlaşılmaktadır. Hatîb elBağdâdî'nin (ö. 463/1071) Tarîhu Bağdad'1 üzerine İbnü'n-Neccâr'ın (ö. 643/1245) yazdı̆̆1 Zeylü Târihu Bă̆dad adlı eserden Ahmed b. Aybek ed-Dimyâtı̂'nin (ö. 845/1445) yaptığı özette Gazâlî̀nin künyesi "Ebû Hâmid b. Ebî Abdillah" olarak kayıtlıdır. (ed-Dimyâtî, 2004, s. 27). Bu kayıt Gazâlî̀nin babasının künyesinin Ebû Abdullah olduğu izlenimi vermektedir. Gazâlî'nin babası Tûs'ta elinde eğirdiği yünleri satarak geçimini sağlayan mütevazi, salih ve fakir bir Müslümandır. (Sübkî, 1976, s. 6/193, 194). Klasik kaynaklar onun ne zaman öldüğü ile ilgili bir tarih vermeseler de ölüm döşeğinde iken Gazâlî ve kardeşi Ahmed'i okuma yazma öğrenimlerini tekellüf etmesi için bir dostuna vasiyet etmesini aktarırlar. (İbn Kesîr, 1993, s. 533). Bu nakil Gazâlî’nin babasının Gazâlî henüz küçük yaşta, rüşt çağına ulaşmadan öldüğüne delalet etmektedir. Modern kaynaklar da bunu teyit etmektedirler.

Klasik kaynaklarda Gazâlî’nin annesi hakkında ise hiçbir bilgiye rastlanılmamaktadır. Modern kaynaklar ise Gazâlı̂’nin annesinin ölüm tarihi ile ilgili bazı ihtimalleri aktarmakla yetinirler. Bazı kaynaklara göre Gazâlî’nin annesi de babası gibi Gazâlî küçük yaşta iken vefat etmiştir. (el-Bakrî, 1943, s. 3). Bazı kaynaklara göre ise Gazâlî'nin annesi oğlunun şöhretin zirvesindeki şaşalı günlerine erişmiştir. (Seyyid Ahmed, 2009, s. 46). Zwemer, Gazâlî’nin annesinin Bağdat’ta iki oğlunun da şan ve 
şöhret zamanlarını görünceye kadar yaşadığını, onun hakkında başka bir bilginin olmadığını söyler; ancak bu bilgiyi tevsik edecek bir kaynak zikretmez. (Zwemer, 1923, s. 39).

Tarihte "Gazâlî" isminde meşhur kişilerin yaşadığı bilenmekteyse de bunların birçoğunun Ebû Hâmid el-Gazâlî ile bir nesep bağı söz konusu değildir. (Zebîdî, 1994, s. 1/18-19). Kaynaklarda Gazâlî'den önce yaşamış Gazâlî ailesinden iki tane daha meşhur âlimin bulunduğu bilgisi yer almaktadır. (Aynî, 2013, s. 42). Bu kişilerden biri Gazâlî’nin babasının amcası veya kendi amcası, diğeri de bu amcanın oğludur. (Zwemer, 1923, s. 37). Bu kişinin daha zayıf bir ihtimalle Gazâlı̂'nin dayısı olduğu iddia edilmektedir. (Akın, 2011, s. 10). Bu kişilerden daha meşhur olanı Sübkî'nin "el-Gazâlî elKebîr el-Kadîm dediği Ahmed b. Muhammed eş-Şeyh Ebû Hâmid Muhammed el-Gazâlî’ dir (ö. 435/ 1043). (Sübkî, 1976, s. 4/87). Şirazî (ö. 476/1083) bu Gazâlî’yi Şafiî fukahâsının ileri gelenlerinden biri olarak tanıtmıştır. (eş-Şirâzî, 1970, s. 133). Gazâlî̀nin tasavvuf temrinlerini kendisinden aldığı hocası Ebû Ali el-Farmedî’nin (ö. 477/1084) hocası olan Ebû Hâmid Ahmed el-Gazâlî, İbnü's-Salâh'a göre Gazâlî’nin amcasıdır. (İsnevî, 2002, s. 2/113). Sübkî ise Büyük Gazâlî'nin kelamcı Gazâlî'nin amcası veya babasının amcası olabileceğini söyler. (Sübkî, 1976, s. 4/90). Diğer Gazâlî ise bu Gazâlî'nin oğlu olup ismi Ahmed, künyesi ise Ebû Hâmid'tir. Zebîdî, bu oğlun ilimde babasını geçtiğini söyler. (Zebîdî, 1994, s.1/19).

Tarihte Ahmed el-Gazâlî olarak meşhur olan vaiz ve mutasavvıf diğer Gazâlî ise Ebû Hâmid elGazâlî'nin kardeşidir. Tam adı Ahmed b. Muhammed b. Muhammed b. Ahmed et-Tûsî'dir. Künyesi Ebu'l-Fütûh, lakabı Mecdü'd-Dîn'dir. (İbnü'l-Cevzî, 1992 s. 17/237-40). Onun, abisi Gazâlî'nin lakapları olan Zeynü'd-Dîn ve Huccetü'l-İslam lakaplarını da taşıdığı zikredilmektedir. (İbnü's-Salah, 1992, s. 1/397; İbn Kâdî Şühbe, h.1407, s. 1/20; el-Münâvî, ts., 1/649; Baltac1, 2013, s.2-3). Klasik kaynaklar onun doğum tarihini zikretmezler. Fakat abisi Gazâlî ile beraber eğitim hayatına başladıklarına dair verilen tarihi bilgiler, onun Gazâlî'den en fazla birkaç sene sonra doğmuş olmasını iltizam etmektedir. Buna göre 451-454/1059-1062 tarih aralığında dünyaya gelmiş olmalıdır. (Alkan, 2017, s. 2/868). 520/1121 senesinde Kazvin'de vefat etmiştir. (İbn Kâdî Şühbe, h.1407, s. 1/2809). Gazâlî’nin birkaç tane kız kardeşinin olduğunu iddia eden modern araştırmacılar varsa da (Watt, 2003, s. 28; Hitti, 1995, s. 182; Çağrıcı, 1996, s.13/350) biz klasik kaynaklarda kız kardeşinin varlığına dair bir kayda rastlayamadik.

Gazâlî’nin hangi tarihte evlendiği hususunda kesin bir tarih zikretmek mümkün olmasa da mektuplarındaki ifadelerden onun Bağdat Nizamiye Medresesi'ne müderris olarak atandıktan sonra evlendiği anlaşılmaktadır. Gazâlî, 504/1110 yılında tekrar Bağdat Nizamiye Medresesine müderris olarak çağrılması üzerine vezir Nizâmüddin Ahmed'e yazdığı mektupta "Şehid Nizamülmülk beni Băgdat'a çă̆ırdı ̆̆ında ben yalnızdım; sorumluluklarını üstlendiğim ailem ve çocuklarım yoktu. Ancak şimdi ailem ve çocuklarım var; onları burada bırakıp kalplerini kırmaya da ruhsatım yoktur." (Yakûbî, 2017, s. 76) demektedir. Bu ifadelerden anlaş1lan Gazâlî Bağdat'a geldikten sonra evlenmiştir. Gazâlî Bağdat'a 484/1091 tarihinde geldiğine göre doğum tarihindeki ihtilafı da dikkate aldığımızda onun otuz yaşından sonra evlendiği ortaya çıkmaktadır. S. M. Zwemer Gazâlî’nin yirmi yaşından önce, (Zwemer, 1923, s. 38) Süleyman Dünya ise Hocas1 el-Cüveynî öldüğünde -ki o zaman Gazâlî yirmi sekiz yaşındadır- Gazâlî'nin evli olduğunu iddia ederler. (Dünya, 1965, s.22). Ancak Gazâlî’nin mektuplarındaki ifadeler bu iddiaları tekzip etmeye yeterlidir.

Gazâlî’nin çocukları hakkında da Klasik kaynaklarda çelişkili bilgiler yer almaktadır. Kendisinden sonra kızlarının yaşadığı bilinmekteyse de (el-Fârisî h. 1382, s. 449; Sübkî, 1976, s. 6/211) kaç kızı olduğu ihtilaflıdır. Onun oğlunun olup olmadığı; varsa küçük yaşta mı öldü yoksa kendisinden sonra yaşadı mı bilinmemektedir. Gazâlî̀ye yakın kaynaklar onun oğlunun olmadığını belirtirler. Fakat 
Gazâlî’ den yaklaşık üç asır sonra yaşayan ünlü hadis âlimi İbn Hacer el-Askalânî (ö. 855/1449) tarih ve biyografi eseri olan İnbâ'u'l-Ğumr bi Ebnâi'l-Umr adlı eserinde sekizinci dedesinin Gazâlî olduğu sanılan Muhyiddîn Ebû Hâmid et-Tûsî isminde bir âlimden bahseder. İbn Hacer, Sıbt İbnü'l-Acemî'nin (ö. 841/1438) de bu kişiden bahsettiğini aktarır. (İbn Hacer, 1969, s. 3/395-96) İbnü’l-İmâd (ö. 1089/1679) ise bu âlimin Gazâlı̂'nin nesebi ile bir bağlantısını zikretmese de isim silsilesini Gazâlî’ye kadar uzatarak İbn Hacer'in sunduğu biyografinin aynısını tekrar eder. (İbnü'l-İmâd, 1986, s. 9/283-84). Tarihçi Şemseddin Sehâvî de (ö. 902/1497) kendisinden ders aldığı hocalarının biyografisini aktardığı ed-Dav'u'l-Lâmi' li Ehli'l-Karni't-Tâsi' adlı eserinde “Gazâlî'nin zürriyetindendir." dediği, nesep silsilesini Gazâlî̀'ye kadar uzattı̆̆ı el-Mahyevî et-Tûsî isimli bir âlim zikreder. (Sehâvî, ts., 1/76, 86). İbn Hacer ile Sehâvî’nin zikrettikleri isim farklı olsa da her ikisinin de verdiği nesep silsilesi aynı kişiyi tanıtmaktadır. Murtezâ ez-Zebîdî, (ö. 1205/1790) ise Misırlı Şazelî sûfîlerinden Ahmed et-Tehtâînin (ö. 1186/1772) kendisine Yukarı Mısır'da Gazâlî’nin torunlarından biriyle karşılaştığını söylediğini aktarır. (Zebîdî, 2006, s. 136). Ahmet Teymür Paşa da Gazâlî’nin soyundan olan üç Gazâlî daha zikreder. Dördüncü Gazâlî Sehâvî'nin de zikrettiği Halep'te h. 830/1427 tarihinde vefat eden ve sekizinci dedesi Ebû Hâmid el-Gazâlî olan Muhammed b. Muhammed el-Gazâlî et-Tûsî'dir. (Teymur Paşa, 1947, s. 113).

Gazâlî'nin kendisinden sonra yaşayan bir oğlu olduğunun ispatı sayılabilecek diğer bir kaynak ise Niğdeli Kadı Ahmed'tir (ö. 734/1333'ten sonra). Kadı Ahmed, el-Veledü'ş-Şefîk ve'l-Hafidü'l-Halîk isimli Farsça muhtasar tarih kitabında Gazâlî'nin kendisinden sonra yaşamış olan bir oğlunun olduğuna delalet eden bilgiler verir. Kendisin de Gazâlî’nin soyundan gelen bir hanımla evli olduğunu söylenen (Ertuğrul, 2019, Ek-2/359) Kadı Ahmed, çocuklarının annesi tarafından dedesi olan Kemâlüddîn Abdülmümin isimli şahsın soy ağacını Gazâlî’ye kadar dayandırır. Bu soy ağacında Gazâlî’nin Ahmet isminde bir oğlunun olduğu görüldüğü gibi Niğdeli Kadı Ahmed'in hanımı da Gazâlî’nin sekizinci kuşak torunudur. (Niğdeli Kadı Ahmet, 2009, s. 2/284; Ertuğrul, 2012, s. 678). Gazzâlînâme müellifi Celâleddîn Hümâî, (ö. 1980) Ali Şir Nevâînin (ö. 906/1501) Mecâlisü'n-Nefâis'inin Farsça tercümesi olan, Sultan Muhammed Fahrî-i Herâtî'nin (ö. 970/1563'ten sonra) Letâifnâme adlı eserinde Hicri dokuzuncu asırda Belh'te Timurlu hükümdarı Sultan Ebû Said Mirza (ö. 873/1469) döneminde Emîru'lİslam Gazâlî namında bir âlimin Ebû Hâmid el-Gazâlî'nin evladından biri olduğu bilgisinin bulunduğunu aktarır. (Hümâî, 1963, s. 217-218).

F. Friffel, Abdülgâfir el-Fârisî’nin Gazâlî’nin sadece kızları olduğu yönünde verdiği bilgiye itimat ederek diğer kaynakların verdiği malumata itibar etmek istemez. Griffel, "Gazâlî̀nin neslinden göze çarpan bir erkek yoktur; en azından biyografi sözlüklerinde zikredilmeyi hak eden biri yoktur." ifadelerini kullanır. Fakat, Gazâlî’nin vefatından iki yıl sonra istinsah edilen Gazâlı̂'nin önemli eserlerinden birinin el yazmasının Gazâlî’nin oğlu olabilecek Muhammed el-Gazâlî tarafindan düzenlenmiş bir icaze içerdiğini belirtir. (Griffel, 2012, s. 108). Burada bahsedilen Muhammed elGazâlî, İbn Hacer el-Askalânî, Sehâvî ve İbnü'l-İmâd'ın eserlerinde zikrettiği kişiyle aynı ismi taşımaktadır. Buna göre İbn Hacer, İbnü'l-İmâd ve Sehâvî'nin bu aktarımlarına itimat edecek olursak Gâzâlî'nin kendisinden sonra bir oğlu yaşamış ve ismi de Hâmid değil Muhammed'tir. Niğdeli Kadı Ahmed'in zikrettiği nesep zincirine göre ise Gazâlî'nin oğlunun ismi Ahmed'tir. Gazâlî'nin ismiyle künyelendiği söylenilen ve küçük yaşta ölen oğlu ise Hâmid’tir. Bir kısmı Gazâlı̀’nin asrına uzak sayılsa da elde edilen referanslar bize Gazâlî’nin bir oğlunun kendisinden sonra yaşamış olabileceği ihtimalinin zayıf olmayacağını göstermektedir. Ancak Gazâlî'nin hayat serüveni hakkında geniş ayrıntıları müşahede ederek sunan el-Fârîsî’nin Gazâlî’nin sadece kızları olduğunu belirtmesi, diğer kaynakların iddialarını zayıflatmaya kafidir. Eğer Gazâlî’nin kendisinden sonra yaşayan bir erkek evladı yoksa 
aksini belirten kayıtlar bir karışıklık eseri olabilir. Buna göre, ya Gazâlî’nin kardeşi Ahmed elGazâlî’nin (ö. 520/1126) soyu Gazâlî ile karıştırılmış ya da Gazâlı̂’nin kızlarından olan erkek torunlarından biri Gazâlî’nin kendisinden sonraki nesep zincirine oğlu olarak dahil edilmiştir. Diğer bir ihtimal de Gazâlî’nin nesebi, Gazâlî’nin kendisinin ya da babasının amcası olan ve "el-Gazâlî el-Kebîr" olarak bilinen diğer Gazâlî’nin nesebi ile karıştırılmış olmasıdır. Zira kaynaklar bu büyük Gazâlî’nin ismi Ahmed, künyesi Ebû Hâmid olan ve ilimde babasını geçen bir oğlunun olduğu bilgisini aktarmaktadır. (Zebîdî, 1994, s. 1/19).

Eldeki tarihi kayıtlar dikkate alındığında Gazâlı̀'nin kendisinden sonra kızlarının yaşadığı anlaşılmaktadır. (Fârisî, h.1382, s.449). Bazı modern kaynaklar da Gazâlî’nin üç tane kızı olduğunu belirtirler. (Zwemer, 1923, s. 38). Feyyûmî, Bağdat'ta Gazâlî'nin sekizinci kuşaktan torunu olan bir şeyhle karşılaştığını bildirir. Feyyûmî’nin burada zikrettiği soyağacına göre Gazâlî’nin kızlarından biri Kuzey Azerbeycan'da bağımsız Şirvan ülkesinin hükümdarı Şirvanşah Tahir b. Ebi'l-Fedâil'in büyük büyükannesi olan Sittü’n-Nisa'dır. (Feyyûmî, ts., s. 2/446; Griffel, 2012, s. 110). Rizâeddin b. Fahreddin Gazâlî’nin Sittü'l-Münâ isminde bir kızı ve bu kızından Ubeydullah isminde bir torununun olduğunu bazı müverrihlerin rivayet ettiklerini söyler. (Fahreddin, 2018, s. 45).

\section{Gazâlı̂’nin Vefatı ve Mezarı}

Gazâlî’nin biyografisinde klasik ve modern bütün kaynakların ittifak ettikleri husus onun vefat tarihidir. Gazâlî, h. 14 Cemâziye's-sânî 505 miladi ise 28 Aralık 1111'de yaklaşık ellileş yaşlarındayken Tâberân'da vefat etmiştir. (Fârisî, h. 1382, s. 449). Kasım Kufralı, Gazâlî’nin vefat tarihini 14 Cemâziyelâhir 505/19 Kanun I 1111 Pazartesi şeklinde verir. (Kufralı, 1987, s. 4/750). Gazâlî’nin son anlarına şahit olan kardeşi Ahmed Gazâlî, onun son anlarını şöyle anlatır: "Pazartesi günü sabah vakti olduğunda abim Ebû Hâmid abdest aldı; namaz klldı ve sonra 'bana kefenimi getirin' dedi. Kefenini kendisine verdik; onu öptü ve başının üstüne koydu. 'Kâinatın tek sahibi olan Allah'ın huzuruna gitmek için gelen emir başımın üstüne.' dedi. Sonra ayaklarını kıble istikametine uzatıp ortalık aydınlanmadan ruhunu teslim etti”. (İbnü'l-Cevzî, 1985, s. 178-79).

Gazâlî, Tâberân Kalesi'nin hemen dışında yapılan bir türbeye defnedildi. (Fârisî, h. 1382, s. 449; Sübkî, 1976, s. 6/211). Sübkî Tâberân kabristanlığındaki türbesinin ziyaret edildiğini söyler. (Sübkî, 1976, s. 6/211). Tâberân'ın h. 791/1398'da tahrip edilmesinden sonra Gazâlî'nin türbesi de ancak bir ucundan tanınabilir hale gelmiştir. Gazâlî'nin mezarı İran'ın bu günkü Meşhed şehri yakınlarında ünlü Şair Firdevsî'nin (ö. 411/1020) mezarının yakınlarındadır. Griffel, Hâruniyye (Harun er-Reşîd'in türbesi) olarak anılan yapının aslında Gazâlî'nin türbesi olduğu kanaatini belirtir. (Griffel, 2012, s. 107108). Bu yapının Merv'deki Sultan Sencer'in (ö. 552/1157) türbesiyle benzer Selçuklu mimari özellikleri taşıması gerek Griffel'i gerekse Çağrıcı'yı buranın Gazâlî’nin türbesi olduğu kanaatine sevk etmiştir. (Çağrıcı, 1996, s. 13/494). Ancak 2004 yapımı Ovidio Salazar'n yönetmenliğini yaptığı AlGhazali: The Alchemist of Happiness (Mutluluğun Kimyacısi) adlı belgesel tarzı yapımda Muhammed Yahagi, Gazâlî'nin mezarının bulunduğu yerin onun gerçek mezarı olmadığını, burasının Gazâlî’nin temsili bir makamı olduğunu söyler. Arkeologların Tûs surlarının ötesinde bir yerde Gazâlî’nin mezarının olduğuna dair birtakım delillerin bulunduğunu belirttiklerini aktarır. (Salazar, 2004, 5-6:10 dk. arası) Araştırmacı Yusuf Sami Kamadan'ın gzt.com sitesinde yayımladığı bir makalede Gazâlî'nin gerçek mezarının eski Tûs şehrini çevreleyen surların dışında şair Firdevsi'nin türbesinin yaklaşık bir kilometre ötesinde boş bir arazinin içinde olduğunun 2007 yılında yapılan arkeolojik kazılar sayesinde tespit edildiğini aktarmıştır. Tespit edilen harabe türbenin resimlerini de siteye koyan Kamadan, İran hükümetinin Gazâlı̂’ye ait kümbetin restorasyonunu mezhepsel ve siyasi saiklerle yapmadığını belirtir. (Kamadan, https://www.gzt.com/mecra/gazzlnin-mezari-ilgi-bekliyor-3424638 (Erişim. 6 Haziran 2021). Maşide Kamit, kaleme aldığı İran'la ilgili gezi notlarında Gazâlı̂’nin gerçek mezarının Hâruniye 
Medresesi'nin/Hârun er-Reşid Türbesi'nin yakınlarında Tâbira isimli bir mevkide bulunduğunu ve burada kazı çalışmalarının devam ettiğini aktarır. (Kamit, 2016, 211). Yakın zamanlarda elde edilen bu bulgular Hârun er-Reşîd'in türbesinin bahçesindeki anıt mezarın Gazâlî'ye ait olmadığını teyit etmektedir. Yeni bulunan mezarın Gazâlî’nin şanına yakışır bir şekilde restore edilip Müslümanların ziyaretine açılarak İslam kültürüne kazandırılması ise İran devletinin insafını beklemektedir.

\section{Sonuç}

Ebû Hâmid el-Gazâlî, dünya kültür mirasına en çok katkısı olan Müslüman düşünürlerin başında gelmektedir. Onun bilimsel mirası geride bıraktığımız on asırdan bugüne tartışılmaya devam etmektedir. Eserleri, ortaya koyduğu fikrî mülahazalar ve tesiri üzerine yapılan münakaşalar hala tazeliğini korumaktadır. İslam düşüncesinin bir dânişmendi (büyük usta) olan Gazâlî’nin biyografisi üzerinde de birçok tartışma yapılmış, onun hayat serüveni belirginleştirilmeye çalışılmıştır. Ancak bu çalışmanın verilerinde de görüleceği üzere onun ölüm tarihinden başka üzerinde ittifak edilen net bir kimliği tespit edilememiştir. Klasik kayakların çoğunun ittifak ettiği h. 450 olan doğum tarihi son zamanlarda yapılan ve Gazâlî’nin hayatını bütüncül bir şekilde analiz eden kaynakların verdiği bilgiler doğrultusunda değişmiştir. Onun ismi konusunda yapılan en fazla tartışma ise isminin Gazâlî "tek z'li" mi yoksa Gazzâlî "çift z'li" mi telaffuz edileceğidir. Bu konuda uzun uzun tartışan düşünürler net bir sonuca götürecek delil tespit edememişlerdir. Klasik kaynaklar Gazâlî’nin ırkı konusunda hiç yorum yapmamaktadırlar. Modern kaynaklar ise onun soyunun Arap veya Acem olduğu konusunda bazı münakaşalar dillendirmişlerdir. Bu münakaşalar ilmî bir sonuç elde etmekten ziyade modern çağın ırkçı zihniyetinin sonuçlarıdır.

Gazâlî’nin ailesi hakkında yapılan tartışmaların en karmaşık olanı onun bir oğlunun olup olmadığıdır. Elde edilen klasik kaynakların verileri onun oğlu olabileceğini belirtmekle beraber oğlunun olmadığı yönündeki belirgin beyanatlar da güvenilir kaynakların ifadelerine dayanmaktadır. Gazâlî̀nin oğlunun olup olmadığı hususundaki bu çelişki, Gazâlî’den sonra Gazâlî ile irtibatlandırılan kişi veya kişilerin nesebinin Gazâlî’nin diğer akrabaları veyahut Gazâlî’nin kardeşiyle karıştırılmış olabileceği ihtimalini akla getirmektedir. Gazâlî'nin annesi hakkında sadece modern kaynakların verdiği bilgiler ise tarihi kaynaklara dayanmayan öznel yorumlar. Son zamanlarda yapılan arkeolojik çalışmalar Gazâlî’nin mezarının yerinin de şimdiye kadar bilinen mevkiden farklı bir yerde olduğunu ortaya koymuştur. 


\section{Kaynakça}

A’sam, Abdülemir. (1998). el-Feylosafü'l-Gazzâli. Kahire: Dâru Kabâ.

Abdü'l-Ğâfir el-Fârisî, Ebü'l-Hasen. (1382). el-Muhtasar min Kitâbi's-Siyâk li Târîhi Nisâbur. thk, Muhammed Kâzım el-Mahmûdî. Tahran: Mirâsü Mektûb

Acar, Abdurrahman. (2018). "Selçuklu-Abbâsî Halifeliği İlişkilerine Genel Bir Bakış". İslam Tarihi ve Medeniyeti. İstanbul: Siyer Yayınları, 6/443-474.

Adamson, Peter. Taylor, Richard C. (2018). “Giriş” İslam Felsefesine Giriş, çev., M. Cüneyt Kaya. 110. İstanbul: Küre Yayınları.

Ahmed Hilmi, Hocazâde. (h.1322). İmâm Gazâlî. İstanbul: Dâru'l-Hilafeti'l-İlmiyye.

Akın, Hanifi “Gazâlî’nin Hayatı”, (Ocak 2011). TYB Akademi, Y. 1, S. 1, ss. 9-14.

Alkan, Ercan (2017). “Ahmed el-Gazzâlî”, İslam Düşünce Atlası, ed. İbrahim Halil Üçer. 2/868-869. İstanbul: İLEM.

Ayderûsî, Abdülkâdir b. Şeyh. (1994). Ta'rifü'l-Ahyâ bi Fezâili'l-Ihyâ, İthâfü's-Sâdeti'l-Müttekîn bi Şerhi İhyâ'ü Ulûmiddîn ile birlikte. Beyrut: Matbaatü'l-Meymeniyye.

Aydın, Abdullah. (2012). Hadis Istılahları Sözlüğü. İstanbul: M.Ü. İlahiyat Fakültesi Vakfı Yayınları,

Aynî, Mehmet Ali. (2013). İslam Düşüncesinin Zirvesi Gazâlî.İ̀stanbul: İnsan Yayınları.

Bakrî, Ebu'l-Ata. (1943). İtirâfâtü'l-Gazâlî. Kahire. Dâru'l-Kütibi'l-Ehliyye

Baltacı, Halil. (Temmuz-Aralık 2013). "Saf Aşkın Üstadı": Ahmed Gazzâlî ve Tasavvuf Anlayışı". Tasavvuf, Y.14, S.32. ss. 1-41.

Böwering, Gerhard. (2001). “Gazâlî, Abû Hâmed Mohammad i”, Encyclopaedia Iranica. 10/358-363. New York: Encyclopaedia Iranica Foundation.

Cemîlî, Abdurrahman Hâmid Der'. (2005). el-İmâmü'l-Gazâlîve Ârâühü'l-Kelâmiyye. Beyrut: Dâru'lKütibi'l- İlmiyye.

Cevâd, Mustafa. “Asru'l-İmâmi'l-Gazâlî”. (1961). Mihricânü'l-Gazâli fî Dımaşk: Ebû Hâmid el-Gazâlî fî'z-Zikrâ'l-Mieviyyeti 't-Tâsiati li Mîlâdihî içinde. 495-510. Dımaşk: y.y.

Corbin, Henry. (2015). İslam Felsefesi Tarihi. çev., Hüseyin Hatemi. İstanbul: İletişim Yayınları.

Cündî el-Yümmî, Bahâüddîn. (1995). es-Sülûk fî Tabakâti’l-Ulemâi ve'l-Mülûk. San'a Mektebetü'lİrşâd.

Çağrıcı, Mustafa. (1996). “Gazzâlî, (Literatür)” Türkiye Diyanet Vakfi İslam Ansiklopedisi. 13/ 530-534. İstanbul: TDV Yayınları

Çağrıcı, Mustafa. (2016). Gazzâlî, Ankara: DİB Yayınları. 
Davutoğlu, Ahmed. (ts.). “Takdim ve Takriz”. mlf. Gazâlî İhyâu 'Ulûmi’d-Dîn. çev. Ahmed Serdaroğlu. 1/1-7. İstanbul: Bedir Yayınevi.

Dimyâtî, Ahmed b. Aybek. (2004). el-Müstefâd min Zeyli Târihi Băğâd. Mustafa Abdülkâdir Atâ, Beyrut: Dâru'l-Kütibî'l-İlmiyye.

Dünyâ, Süleyman (1965). el-Hakîkatü fi Nazari'l-Gazâlî. Mısır: Dâru'l-Ma'ârif.

Ebû Lihye, Nureddin. (2016). el-Islâhu'l-İctimâî inde Ebî Hâmid el-Gazâlî. b.y: Dâru'l-Envâr.

el-Mardînî, Yusuf Sıdk1. (2015). İhyâ Tercümesi ve Şerhi. İstanbul: Türkiye Yazma Eserler Kurumu Başkanlığı Yayınları.

Emîn, Hüseyin. (1963). el-Gazâlî Fakîhen ve Feylesûfen ve Mutasavvıfen. Bağdat: Matbaatü'l-İrşâd.

Emîn, Muhsin. (1983). A'yânü 'ş-Şî̀'a. Beyrut: Dâru't-Ta'âruf.

Ertuğrul, Ali. (2012). “İmam Ebû Hâmid el-Gazzâlî’nin Anadolu'daki Torunları”. C.Ü. İlahiyat Fakültesi Dergisi. C.XVI, S. 2, ss. 667-688.

Ertuğrul, Ali. (2019). "Niğdeli Kadı Ahmed”, TDV İslam Ansiklopedisi. Ek-2/359-360. İstanbul: TDV Yayınları.

Fahreddin, Rızâeddin b.. (2018). İmam Gazzâlî, haz, Leyla Yakupoğlu Boran. İstanbul: Büyüyen Ay Yayınları.

Fâhurî, Hannâ. Cerr, Halil. (1993). Tarihu'l-Felsefeti'l-Arabiyye. Beyrut: Dâru'l-Celil.

Feyyûmî, Ahmed b. Muhammed. (ts). el-Misbâhu'l-Münîr. Beyrut: el-Mektebetü'l-İlmiyye.

Feyyûmî, Muhammed İbrahim. (ts.). el-İmâmü'l-Gazâlî ve Alâkatü'l-Akli bi'l-Yakîn. Kahire: Dâru'lFikr.

Frye, Richard N. The Histories of Nishapur, Yazma Metin 2, $20 \mathrm{~b}$.

Frye, Richard N. (1965). The Histories of Nishapur. Cambridge-Massachusetts: Harvard University Press.

Gâlib, Mustafa. (1979). el-Gazâlî. Beyrut: Dâru ve Mektebetü Hilâl.

Garden, Kenneth. (2019). İslamın İlk Müceddidi. çev, Abdullah Özkan. İstanbul: Klasik Yayınları.

Gazâli, Ebû Hâmid. (1416). el-Munkız min'd-Dalâl. Mecmû́atü Resâil el-İmam el-Gazâlî içinde. Beyrut: Dâru'l-Fikr

Gazâlî, Ebû Hâmid. (2009). Fedâihu'l-Bâtıniyye, nşr, Muhammed Ali el-Kutb. (Beyrut: el-Mektebetü’lAsriyye.

Gazâlî, Ebû Hâmid. (ts). Kânunu't-Te'vîl, Mecmû'atü Resâil el-İmam el-Gazâlî içinde. Kahire: Mektebetü’t-Tevfîkiyye.

Gencer, Bedri. (2015). “Teodiseyi Aşan Gazâlî” Doğu’dan Batı’ya Düşüncenin Serüveni Felsefe, Ahlak ve Kelâmın Sentezi. 6/675-696. İstanbul: İnsan Yayınları. 
Goldziher, Ignaz. (1959). el-Akîdetü ve'ş-Şerîatü fi'l-İslam. çev., Muhammed Yusuf Musa vd.. Mısır: Dâru'l-Kütibi'l-Hadîse,

Goldziher, İgnace. (1993). Klasik Arap Literatürü. çev., Azmi Yüksel Rahmi Er. Ankara: İmaj Yayınları.

Gosche, Richard. (1858). "Über Ghazzâlîs Leben und Werke", Philologische und Historische Abhandlungen der Königlichen Akademie der Wissenschaften zu Berlin. ss. 239-311.

Griffel, Frank. (2017). “Al-Ghazâlis (d.1111) İncoherence of The Fhilosophers”, İslamic Fhilosophy içinde, ed. Khaled el-Rouayheb, Sabine Schmidtke, 191-209. New York: Oxford University Press.

Griffel, Frank. (2013). “el-Ğazâlî mi el-Ğazzâlî mi? Şam’daki Eyyûbî ve Memlük Tarihçileri Arasındaki Canlı bir Tartışma Üzerine”. çev, Tuna Tunagöz. Fırat Üniversitesi Ilâhiyat Fakültesi Dergisi, 18:1, ss. 205-2015.

Griffel, Frank. (2020). “İbn Sînâcı Felsefeyle Meşgul Olan Kelâm: Gazzâlî’nin Tehâfütü’l-Felâsife’si ve İbnü'l-Melâhimî'nin Tuhfetü'l-Mütekellimîn fi'r-Red ale'l-Felâsife'si” Başlangiçtan Günümüze İslam Kelamı içinde, ed. Sabine Schmidtke, çevirenler, Orhan Şener Koloğlu vd., 568594. İstanbul: Küre Yayınları,

Griffel, Frank. (2012). Gazâlî'nin Felsefi Kelâmı. çev, İbrahim Halil Üçer, Muhammed Fatih Kılıç. İstanbul: Klasik Yayınları.

Griffel, Frank, “al-Ghazali”, Erişim Adresi, https://plato.stanford.edu/entries/al-ghazali/. Erişim Tarihi, 13. 01. 2021.

Hafâcî, Şahâbeddin. (ts.). Nesîmü'r-Riyâz fỉ Şerh-i Şifâi 'l-Kâdî İâz. Beyrut: Dâru'l-Kütibi'l-İlmiyye.

Hammer-Purgstall, Joseph Freiherr von. (1838). O Kind Dei Berühmte Ethische Abhandlung Ghasali's, Viyana: Gedruckt bey A. Strauss's Sell Witwe.

Hitti, Philip K. (1995). Arap Tarihinin Mimarları, çev, Ali Zengin. İstanbul: Risale Yayınları, Hitti, Philip K. (2020). Siyasi ve Kültürel İslam Tarihi, çev, Salih Tuğ. İstanbul: Bilge Kültür-Sanat.

Hodgson, M.S.G. (2020). İslam’ın Serüveni. çev. Berkay Ersöz. Ankara: Phoenix Yayınevi.

Hümâî, Celâleddîn. (1382/1963). Gazzâlînâme. Tahran: Kitapfurûşî-yi Furûğ̂i.

İbn Asâkir, Ebü'l-Kâsım. (1995). Târîhu Medîneti Dımaşk, thk., Ömer b. Garâme el-Amrevî, Beyrut: Dâru'l-Fikr.

İbn Asâkir, Ebü’l-Kâsım. (1404/1981). Tebyînü Kezibi'l-Müfterî. Beyrut: Dâru'l-Kitâbi'l-Arabî.

İbn Hacer el-Askalânî, (1969). Ebü'l-Fazl. İnbâ'u'l-Ğumr bi Ebnâi'l-Umr. thk., Hasan Habeşî. Mısır: el-Meclisü'l-A'lâ li'ş-Şü'ûni'l-İslâmiyye,

İbn Haldûn, Ebû Zeyd. (2004). Mukaddime, çev., Süleyman Uludağ. İstanbul: Dergâh Yayınları.

İbn Hallikân, Ebü'l-Abbas. (1978). Vefeyâtü'l-A'yan, thk., İhsan Abbas. Beyrut: Dâru Sâdır.

İbn Havkal, Ebü'l-Kâsım. (2017). 10. Asırda İslam Coğrafyası. çev., Ramazan Şeşen. İstanbul: Yeditepe Yayınevi. 
İbn Kâdî Şübhe, Takıyyüddîn. (h.1407). Tabakâtü'şs-Şâfi'iyye. thk, el-Hâfız Abüdülalîm Hân. Beyrut: Âlemü'l-Kütüb.

İbn Kesîr, Ebü'l-Fidâ. (1993). Tabakâtü'ş-Şâfi 'iyyîn. thk., Ahmed Ömer Hâşim. Kahire: Mektebetü'sSekâfetü'd-Diniyye.

İbn Kesîr, Ebü'l-Fifâ. (1988). el-Bidâye ve'n-Nihâye, thk., Ali Şeyrâ. Beyrut: Dâru İhyaü't-Türâsi'lArabî.

İbn Manzûr, (1414). Ebü'l-Fazl. Lisanü'l-Arab. Beyrut: Dâru Sâdır.

İbn Receb, Ebü'l-Ferec. (2005). Zeylü Tabakâti'l-Hanâbile. thk., Abdurrahman b. Süleyman elUseymîn. Riyad: Mektebetü'l-Ubeykân.

İbnü'l-Arabî, Ebû Bekir. (1974). el-Avâsım mine’l-Kavâsım. thk., Ammâr Tâlibî. Kahire: Mektebetü Dârü’t-Türâs.

İbnü'l-Esîr, İzzeddin. (1980). el-Lübâb fî Tehzîbi'l-Ensâb. Beyrut: Dâru Sâdır.

İbnü'l-İmâd, Ebü'l-Felâh. (1986). Şezerâtü'z-Zeheb, thk. Mahmud el-Arnavud, Beyrut, Dımaşk: Dâru İbn Kesîr.

İbnü'l-Mülakkın, Ebû Hafs Sirâcüddîn. (1997). el-Ikdü'l-Müzheb fi Tabakâti Hameleti'l-Mezheb. thk., Eymen Nasr el-Ezheri, Seyyid Mühenî. Beyrut: Daru'l-Kütübi'l-İlmiyye.

İbnü’l-Müstevfî, Ebü’l-Berekât. (1980). Târîhu Erbil. thk., Sâmî es-Sakkâr. Irak: Dâru'r-Resîd.

İbnü’n-Neccâr el-Bağdâdî, Ebû Abdillah. (2004). el-Müstefâd Zeylü Târîhu Bağdâd. thk., Mustafa Abdülkâdir Atâ. Beyrut: Dâru'l-Kütibi'l-İlmiyye.

İbnü’s-Salâh, eş-Şehrezûrî, Ebû Amr. (1992). Tabakâtü'l-Fukahâi’ş-Şâfi'iyye. thk, Muhyiddîn Ali Necîb. Beyrut: Dâru'l-Beşâiri'l-İslâmiyye.

İbnü't-T1ktaka, Ebû Cafer. (1997). el-Fahrî fì Âdâbi's-Sultaniyye ve'd-Düvelü'l-İslamiyye. thk., Abdülkâdir Mahmud Mâyû. Beyrut: Dâru'l-Kalemi'l-Arabî.

İbnü'l-Cevzî, Ebü'l-Ferec. (1992). el-Muntazam fî Târihi'l-Mülûk ve'l-Ümem. thk, Muhammed Abdülkâdir Atâ, Mustafa Abdülkâdir Atâ. Beyrut: Dâru'l-Kütübi'l-ilmiyye.

İbnü'l-Cevzî, Ebü'l-Ferec. (1406/1985). es-Sebâtü indel'Memât. thk., Abdullah el-Leysî el-Ensârî. Beyrut: Müessesetü'l-Kütübi’s-Sekâfiyye.

İsnevî, Ebû Muhammed. (2002).Tabakâtü’ş-Şafi ‘iyye. thk, Kemal Yusuf el-Hût. Beyrut: Dâru’lKütübi'l-İlmiyye.

İstahrî, Ebû İshak İbrahim. (2004). el-Mesâlik ve'l-Memâlik. Beyrut: Dâru Sâdır.

Kamadan, Yusuf Sami. Gazâlî’nin Mezarl İlgi Bekliyor. Erişim Adresi, https://www.gzt.com/mecra/gazzlnin-mezari-ilgi-bekliyor-3424638. Erişim Tarihi 6.06. 2021.

Kamit, Maşide. (2016). "Gezi Notları "İran Araştırma ve İnceleme Gezisi” (16-22 Mayıs 2016)". ISTEM. Y.14, S.27, ss. 205-225. 
Kandemir, M. Yaşar (1998). “Abdülgâfir el-Fârisî”. Türkiye Diyanet Vakfi İslam Ansiklopedisi. 1/203204. İstanbul: TDV Yayınları.

Kannevcî, Sıddık Hasan Han. (2002). Ebcedü'l-Ulûm. by: Dâru İbn Hazm.

Kaya, M. Cüneyd. (2017). “Gazâlî”, İslam Düşünce Atlası içinde, ed., İbrahim Halil Üçer. 2/525-531. İstanbul: İLEM.

Kazvînî, Zekeriyyâ. (ts.). Âsâru'l-Bilâd ve Ahbâru'l-ỉbâd. Beyrut: Dâru Sâdır.

Kebisî, Hamid. (1971). “Muhakkikin Ön Sözü” Şifâü'l-Ğalîl, mlf. Gazâlî. Bağdat: Matba'atü’l-İrşad.

Kılavuz, A. Saim. (1989). "Ali er-Rıâa”, Türkiye Diyanet Vakfi İslam Ansiklopedisi. 2/436-438. İstanbul: TDV Yayınları.

Kufralı, Kasım. (1987). “Gazzâli” İslam Ansiklopedisi. 4/748-760. İstanbul: Milli Eğitim Basımevi.

Macdonald, D. B. (1899). "The Life of al-Ghazzâlî, with Especial Reference to His Religious Experiences and Opinions” Journal of the American Oriental Society, Volume 20, ss. 71-132.

Mehmed Hafîd, Âşirefendizâde. (2018). Ed-Dürerü'l-Müntehabâti'l-Mensûre fi Islâhi'l-Galatâti'lMeşhûre, haz., Yakup Yılmaz. Ankara: Türk Dil Kurumu Yayınları.

Merhaba, Abdurrahman. (1993). Hitâbü'l-Felsefeti'l-Arabiyyeti'l-İslâmiyye. Beyrut: Müessesetü İzziddîn.

Muavvız, Ali. Abdülmevcûd, Adil. (1997). "Muhakkiklerin Ön Sözü” mlf., Gazâlî. el-Vecîz fî Fıkhi İmâmi'ş-Şâfi' ’̂, 1-65. Beyrut: Dâru'l-Erkam İbn Ebi'l-Erkam.

Mübarek, Zeki. (2012). el-Ahlâku inde'l-Gazâli. Kahire: Kelimâtün Arabiyyetün li’t-Tercümeti ve'nNeşr.

Münâvî, Muhammed Abdürrauf. (1318). Şerhu'ş-Şemâili'n-Nebeviyye ve'l-Hasâisi'l-Muhammediyye. Cem'u'l-Vesâil fi Şerhi 'ş-Şemâil ile birlikte. Kahire: el-Matbaatü'ş-Şarkıyye.

Münâvî, Muhammed Abdürraûf. (ts.). el-Kevâkibü'd-Dürriyye. thk., Abdülhamid Salih Hamdan. Kahire: el-Mektebetü'1-Ezheriyye.

Nasr, Seyyid Hüseyin. (1991). “İslam Düşüncesinin Soykütüğü’. çev., Yusuf Kaplan. Umran,1/1 (Nisan 1991). ss.1-16.

Nevevî, Ebû Zekeriyyâ. (1994). et-Tibyân fî Âdâbi Hameleti'l-Kur'an. thk., Muhammed el-Haccâr. Beyrut: Dâru İbn Hazm.

Nu’mânî, Şiblî. (2012). Gazâlî. çev, Yusuf Kara. İstanbul: Kayıhan Yayınları.

Rizâ, M. Reşid, (1907). “Ebû Hâmid el-Gazâlî”. el-Menâr. 10/7, (Eylül 1907): 502-522.

Rizâ, Muhammed. (1924). Ebû Hâmid el-Gazâlî. Misır: Matba'atü'l-Vefd.

Rufâî, Ahmed Ferid. (1936). el-Gazâlî. Misır: Matbû'atü Dâru'l-Me'mûn.

Sadefî, Halil b. Aybek. (2000). el-Vâfí bi'l-Vefâyât. Beyrut: Dâru İhyâi't-Türâs. 
Salazar, Ovidio. (2004). Al-Ghazali: The Alchemist of Happiness (Mutluluğun Kimyacısı), (Belgesel).

Sallâbî, Muhammed Ali. (2017). el-İmâmü'l-Gazâlî. İstanbul: Ravza Yayınc1lık.

Sâmî, Salih Ahmed. (1992). el-İmâmü'l-Gazâlî Huccetü'l-İslam ve Müceddidü'l-Mietü'l-Hâmise. Dımaşk: Dâru'l-Kalem.

Sâmi, Şemseddin, (1896). Kâmûsü'l-A'lâm. İstanbul: Mihrân Matbaas1.

Sarîfînî, Ebû İshak. (1362/1983). Târîh-i Nî̧şâûr el-Müntehab mine's-Siyâk, haz., Muhammed Kâzım el-Mahmûdî. Kum: Cemâatü'l-Müderrisîn fi'l-Havzati'l-İlmiyye.

Sehâvî, Şemseddin. (ts.). ed-Dav'u'l-Lâmi' li Ehli'l-Karni't-Tâsi'. Beyrut: Menşârâtü Dâru Mektebeti Hayat.

Sem'ânî, Abdülkerîm b. Muhammed. (1962). el-Ensâb. thk., Abdurrahman b. Yahya el-Muallimî elYemânî, vd.. Haydarâbâd: y.y.

Sem’ânî, Abdülkerîm b. Muhammed. (1912). el-Ensâb, Tıpkıbs., haz., D. S. Margoliouth, (London: E.J. Brill.

Seyyid Ahmed, Abdülfettah Muhammed. (2009). et-Tasavvufü beyne'l-Gazâlî ve İbn Teymiye. ElMansura: Dâru'l-Vefâ.

Sibt İbnü'l-Cevzî, Ebü'l-Muzaffer. (2013). Mir'âtü'z-Zamân fi Târîhu'l-A'yân. thk, Muhammed Berekât vd..Şam: Dâru'r-Risâleti'l-Âlemiyye.

Smith, Margaret. (1983). Al-Ghazâlî the Mystic. Lahore: Hijra İnternational Publishers.

Starr, S. Frederic. (2020). Kayıp Aydınlanma. çev., Yusuf Selman İnanç. İstanbul: Kronik Kitap.

Streck, M. (1979). "Meşhed”, İslam Ansiklopedisi. 8:145-159. İstanbul: Milli Eğitim Basımevi.

Sübkî, Tâceddin. (1976). Tabakâtü'ş-Şâfi 'iyyeti’l-Kübrâ. thk, Mahmud Muhammed et-Tanâhî, Abdulfettah Muhammed el-Hılv. Kahire: İsâel-Bâbî el-Halebî.

Sürur, Taha Abdülbakî. (1940). el-Gazâlî. by.: Dâru'l-Maârîf.

Şerkâvi, Abdullah b. Hicazî. et-Tuhfetü'l-Behiyye fî Tabakâti'ş-Şâfi'ıyye, YE. Berlin: Berlin Devlet Kütüphanesi.

Şeyh, M. Said. (2014). “Gazzâlî” İslam Düşünce Tarihi. çev., Mustafa Armağan, Haz., M.M. Şerif. 1/731-770. İstanbul: İnsan Yayınları.

Şirâzî, Ebû ishak (1970). Tabakâtü'l-Fukahâ. thk., İhsan Abbas. Beyrut: Dâru'r-Râidi'l-Arabî.

Tâmir, Ârif. (1987). el-Gazâlî, beyne'l-Felsefeti ve'd-Dîn. London: Riad el-Rayyes Books.

Teymur Paşa, Ahmet. (1947). Zabtu'l-A 'lâm. Kahire: Dâru İhyâi'l-Kütübi’l-Arabiyye.

Ülken, H. Ziya. (2004). Eski Yunan'dan Çağdaş Düşünceye Doğru İslam Felsefesi Kaynakları ve Etkileri. İstanbul: Ülken Yayınları.

Ülken, H. Ziya. (1946). İslam Düşüncesi. İstanbul: Rıza Koşkun Matbaası, 
Ülken, H. Ziya. (1957). İslam Felsefesi Tarihi. İstanbul: Osman Yalçın Matbaası.

Watt, W. M. (1985). İslamic Fhilosophy and Theology. Edinburgh: Edinburgh University Press.

Watt, W.M. (2003). Müslüman Aydın. çev., Hanifi Özcan. Samsun: Etüt Yayınları.

Yâfi'î, Ebû Muhammed. (1997). Mir 'âtü'l-Cenân ve İbretü'l-Yekzân. Beyrut: Dâru'l-Kütübi'l-İlmiyye.

Yakûbî, Şeyh Muhammed. (2017). Gazzâlî’nin Mektupları. çev, Merve Kelebek. İstanbul: İnkılap Yayınları.

Yâkût el-Hamevî, Ebû Abdillah. (1995). Mu'cemü'l-Büldân. Beyrut: Dâr-u Sâdır.

Zebîdî, Muhammed Murtaza. (2006). el-Mu'cemü'l-Muhtass. thk., Nizam Muhammed Salih Yakûbî, Muhammed b. Nâsır el-Acemî. Buyrut: Dâru'l-Beşâiri'l-İslâmiyye.

Zebîdî, Muhammed Murtaza, (1994). İthâfü's-Sâdeti'l-Müttekîn bi Şerhi İhyâ'ü Ulûmiddîn, Beyrut: Matbaatü'l-Meymeniyye.

Zebîdî, Muhammed Murtazâ. (ts.). Tâcü'l-Arûs. b.y., Dâru'l-Hidâye.

Zehebî, Ebû Abdillah Şemsüddin. (1985). el-İber fi Tarihi men Ğaber. thk., Ebû Hâcir Muhammed Said. Beyrut, Dâru'l-Kütibi'l-İlmiyye.

Zehebî, Ebû Abdillah Şemsüddin. (1998). Tezkiretü'l-Huffaz. Beyrut: Dâru'l-Kütibi'l-ìlmiyye.

Zehebî, Ebû Abdillah. (2006). Siyeru A 'lâmü'n-Nübelâ. Kahire: Dâru'l-Hadis.

Zerrinkub, Abdülhüseyin. (2007). Medreseden Kaçış İmam Gazzâlî'nin Hayatı, Fikirleri ve Eserleri. çev, Hikmet Gök. İstanbul: Ağaç Yayınları.

Zeydân, Corcî. (2012). Târihu Âdâbi'l-Lügati'l-Arabiyye. Kahire: Müessesetü Hindâvî.

Zwemer, Samuel Marinus. (1923). Kitabü'l-Gavvâs ve'l-Leâlî ev Tecümetü'l-Hayati'l-Hucceti'l-İslam el-Gazâlî. Misır: Matba'atü Nesil. 